Review

\title{
Egyptian and Greek Water Cultures and Hydro-Technologies in Ancient Times
}

\author{
Abdelkader T. Ahmed ${ }^{1,2, *}{ }^{\mathbb{C}}$, Fatma El Gohary ${ }^{3}$, Vasileios A. Tzanakakis ${ }^{4}$ and \\ Andreas N. Angelakis 5,6 (D) \\ 1 Civil Engineering Department, Faculty of Engineering, Aswan University, Aswan 81542, Egypt \\ Civil Engineering Department, Faculty of Engineering, Islamic University, Madinah 42351, Saudi Arabia \\ Water Pollution Research Department, National Research Centre, Cairo 12622, Egypt; fgohary@outlook.com \\ 4 Department of Agriculture, School of Agricultural Science, Hellenic Mediterranean University, Iraklion, \\ 71410 Crete, Greece; vtzanakakis@hmu.gr \\ 5 HAO-Demeter, Agricultural Research Institution of Crete, 71300 Iraklion, Greece; angelak@edeya.gr \\ 6 Union of Water Supply and Sewerage Enterprises, 41222 Larissa, Greece \\ * Correspondence: dratahmed@yahoo.com
}

Received: 2 October 2020; Accepted: 19 November 2020; Published: 23 November 2020

\begin{abstract}
Egyptian and Greek ancient civilizations prevailed in eastern Mediterranean since prehistoric times. The Egyptian civilization is thought to have been begun in about $3150 \mathrm{BC}$ until $31 \mathrm{BC}$. For the ancient Greek civilization, it started in the period of Minoan (ca. 3200 BC) up to the ending of the Hellenistic era. There are various parallels and dissimilarities between both civilizations. They co-existed during a certain timeframe (from ca. 2000 to ca. 146 BC); however, they were in two different geographic areas. Both civilizations were massive traders, subsequently, they deeply influenced the regional civilizations which have developed in that region. Various scientific and technological principles were established by both civilizations through their long histories. Water management was one of these major technologies. Accordingly, they have significantly influenced the ancient world's hydro-technologies. In this review, a comparison of water culture issues and hydro-structures was adopted through the extended history of the ancient Egyptians and Greeks. The specific objectives of the work are to study the parallel historical cultures and hydro-technologies, assessing similarities and differences, and to analyze their progress since primitive times. The tools adopted for the research include visits to historical aeras and museums, comments, consultations, correlation and exhibitions available in the cyberspace. Review results herein showed that dams and canals were constructed in ancient Egypt to manage the flood of the Nile river and develop irrigation systems from ca. 6000 BC. In the second millennium BC, Minoans managed the flow of the streams via two dams, to protect arable land from destruction after intense rainfall and to irrigate their farms. Additional results showed that ancient Egyptians and Greeks invented many devices for lifting water for plant irrigation such as the shadouf, sakia and tympanum and pumps, of which some were already in use in Mesopotamia for irrigating small plots. The ancient Egyptians were the first who discovered the principle and the basis of coagulation (after ca. $1500 \mathrm{BC}$ ). They used the alum for accelerating the settlement of the particles. Additionally, the ancient Greeks developed several advanced water treatment technologies since the prehistoric times. To sum up, the study captured many similarities between two civilizations in water technologies. In addition, it confirmed the sustainability and durability of several of those hydro-technologies since they are still in use up to now in many places.
\end{abstract}

Keywords: Ancient Egypt and Greece; irrigation: water management; water supply; sustainability; wastewater; storm-water management 


\section{Prolegomena}

Much archaeological evidence suggests that there was contact between ancient Egyptian and Greek civilizations. For example, wood was one of the raw materials that was commercially used and traded to nearby countries such as Egypt, Syria and Cyprus. Besides exchanging natural resources, the Minoans also adopted from the surrounding cultures art concepts and tools as evident in Egypt's influence on the Minoan wall paintings [1]. A Minoan wall fresco from room 5 of west House of Akroriri city in the Aegean island Santorin (Thera) is shown in Figure 1 depicting the Nile river and its banks in Egypt [2]. Furthermore, they continued to trade with Egypt and the Middle East-tin, ivory, copper and gold - while they built a lined road network to link the main cultural centers. This history of ancient Greeks to Egypt was continued by Mycenaean culture (ca. 1600-1100 BC).

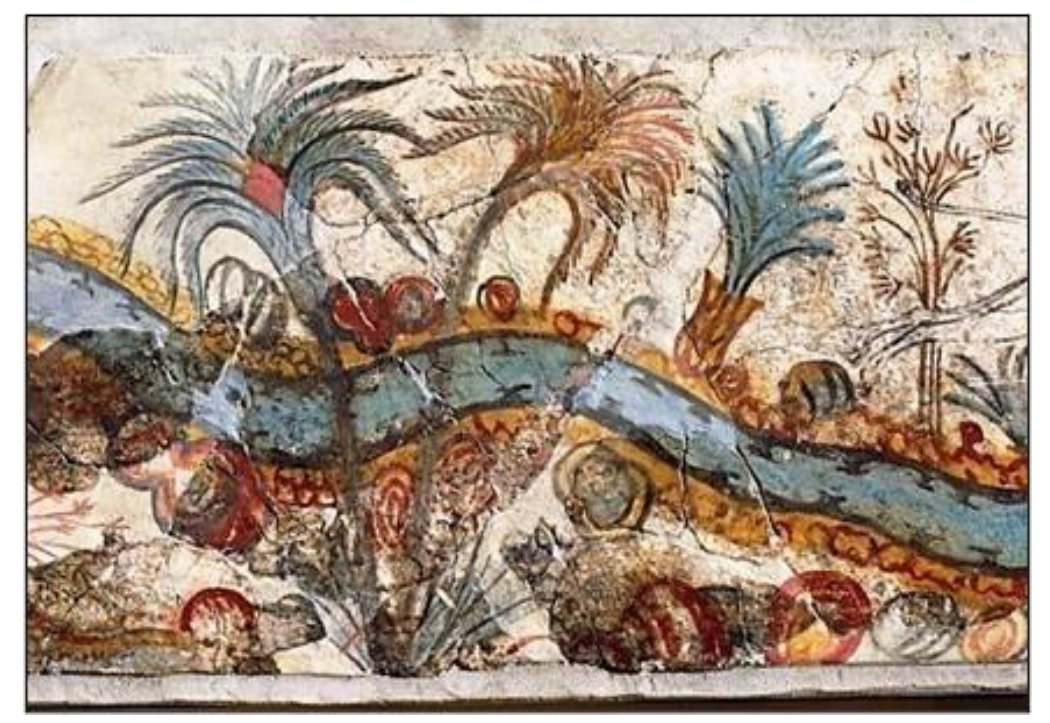

Figure 1. This landscape depicts a river (i.e., Nile) and on its banks are depicted wild ducks, which are being chased by panthers, among papyri and palm trees [2].

Following the failure of Minoan and Mycenaean civilizations and the consequent Greek dark ages (ca. 1100-750 BC), a "renaissance" of Greek culture grew in the 7th century BC and with it came renewed contact with the East and its two great river civilizations of Mesopotamia and the Nile. The city of Naucratis was founded in Ancient Egypt. It was placed on the Canopic branch of the Nile river, $72 \mathrm{~km}$ from the Mediterranean sea. It was the first and the only permanent Greek camp in Egypt, acting as a mutual relationship for the exchange of art and culture between ancient Greece and Egypt [3].

Recently, Villing [4] reported that Naukratis must date back to the late 7th century BC, not just to the time of the pharaoh Amasis (ca. 560-550 and ca. 530-520 BC), as one might be tempted to think. The Greeks Ionians and Carians are known to have served as mercenaries of Psammetichus I armies on his campaigns in the Nile valley. He ruled Egypt in the beginning of the 26th Dynasty of Egypt (from ca. 664 to ca. 610 BC). However, Naucratis was declared a Greek free-trade zone by the pharaoh Amasis in ca. 560 BC. Herodotus, visited Egypt in ca. 500 BC, declared Greeks as one of the first groups of outsiders that ever lived in Egypt [3].

The Greek mercenaries and traders spread stories back home about Egypt and gave Egyptian things Greek names, such as the Nile estuary being called a delta after the shape of the Greek letter. The word Egypt itself may have come from Homer's Aigyptos, a Hellenization of the word Hikuptah ("mansion of the soul of Ptah") [5]. Furthermore, Garnett [5] stated the following: "I was watching a special on Egyptian gods today, and this question came up. When one society conquers another (as when the Greeks conquered the Egyptians), usually elements of the conquered society are incorporated into the conquerors. Are there any Greek gods that came out of the Egyptian conquest?" 
During their long histories, the ancient Egyptians and Greeks developed several scientific areas on culture and managing of the water resources. The main emphasis of these fields involves aqueducts, hydrogeology, water and wastewater management, stormwater control, irrigation, as well as the use of water for restoration purposes [6]. These technological achievements developed by both cultures since the prehistoric times were further improved scientifically during the historical times.

From ca. late 7th century BC, the Nile Delta port of Naukratis was the world's gateway to Egypt. It was a flourishing and cosmopolitan river port on the Canopic branch of the Nile. Archeological evidence suggests a significant decline of Naucratis, in the mid-3rd century AD and until the 4th century AD, possibly associated with economic and demographic problems in Egypt and the Roman Empire. Meanwhile, Alexandria was the new Hellenistic center in Egypt and the main link between Greece and the rich Nile Valley. Alexander the Great conquered Achaemenid Empire in 332-333 BC and founded Great Alexandria which was not only a commercial center but a significant School of sciences. It was a continuation of Athens Platonic Academy (founded in 387-386 BC) and Aristotle Lyceum (founded in 334-335 BC). Alexandria grew rapidly as the most important center between Hellenistic and Egyptian cultures. The city remained for almost 1000 years the capital of Ptolemaic Egypt and Roman and Byzantine Egypt until it was conquered by the Muslims in 641 AD, when a new capital was founded in Fustat. Later it was incorporated into Cairo.

At that time, Alexandria was known for its Lighthouse (Pharos), one of the seven wonders of the ancient world, and its Great Library, considered the largest in the ancient world. Alexandria was considered the spiritual and cultural center of the ancient Mediterranean world until the end of the Hellenistic era and before its occupation by the Romans [7]. The Greek government in most locations had been replaced by the Romans, however, the Romans used Greek technologies and advanced them further. Additionally, the Romans significantly enhanced the implementation and size of the water projects in most large cities [8]. The hydro-technologies developed by Greeks and Romans are not only historical remains, but they are supporting modern attainments in water management and engineering applications.

In this review, a comparison of water culture issues and hydro-structures was adopted through the extended history of the ancient Egyptians and Greeks. The specific objectives of the work are to study the parallel historical cultures and hydro-technologies, assessing similarities and differences, and to analyze their progress since primitive times.

\section{Research Methodology}

The research methodology followed included visits and explorations of the archeological places and museums in Egypt and Greece. Moreover, comments, consultations, correlations and exhibitions available in the cyberspace were considered. Finally, a thorough review of the relevant references describing the historical hydro customs of ancient people in the ancient places was conducted. Photos were taken directly from these places sometimes and the majority were collected from the literature review.

The comparison was focused on (a) water engineering, e.g., water lifting devices, aqueducts, rainwater harvesting, agricultural irrigation and related practices, water treatment and hygienic issues, and (b) water and health with emphasis on the foundation of the Medical school in Alexandria and the crucial role of the water in medicine. Finally, the major issues of the above comparisons are discussed focusing on similarities of hydro-technologies concluding with potential lessons learnt.

The main historical phases for Egypt and Greece in a chronological order are shown in Table 1. The major historical periods examined in this study includes prehistoric (i.e., Neolithic and Bronze Age), Historical (i.e., Classical, Hellenistic and Roman), Medieval, Early Modern and finally Contemporary times. For Greece, besides Byzantine times (ca. 330-1453 AD), Egyptian (ca. 824-961 AD) (referring mainly to Crete), Early and Mid-Modern times (ca. 843-1205 AD), Venetian (referring mainly to Crete (ca. 1205-1669 AD) and Ionian islands (ca. 1386-1789 AD)) and Ottoman period (ca. 1453-1922) for 
what it should be noticed that Crete island was liberated in 1898 and the Dodecanese islands were liberated from Ottomans in 1912 and from Italians in 1947.

Table 1. The major historical periods considered in this study.

\begin{tabular}{|c|c|c|}
\hline Years (ca.) & Period of Egypt & Period of Greece \\
\hline $7000-1100$ BC & $\begin{array}{c}\text { Prehistoric Egypt } \\
\text { Neolithic (ca. 5700-3200 BC) } \\
\text { Bronze Age (ca. 3200-1150 BC) }\end{array}$ & $\begin{array}{l}\text { Prehistoric times, i.e.: } \\
\text { Neolithic (ca. 7000-3200 BC) } \\
\text { Bronze Age (ca. 3200-1150 BC) } \\
\text { Mycenaean (ca.1600-1100 BC) }\end{array}$ \\
\hline 1150-750 BC & Dark Age & Dark Ages or Geometric times \\
\hline $750 \mathrm{BC}-330 \mathrm{AD}$ & $\begin{array}{c}\text { Historical times, i.e.: } \\
\text { Dynasty of Egypt: (ca. 664-610 BC) } \\
\text { Classical Age: (ca. 500-336 BC) } \\
\text { Roman and Byzantine Egypt 30BC-641 AD }\end{array}$ & $\begin{array}{c}\text { Historical times, i.e.: } \\
\text { Archaic (ca. 750-500 BC) } \\
\text { Classical (ca. 500-323 BC) } \\
\text { Hellenistic (ca. 323-146 BC) } \\
\text { Roman (ca. 146 BC-330 AD) }\end{array}$ \\
\hline $330-1200 \mathrm{AD}$ & Medieval Egypt: 641-1517 AD & $\begin{array}{c}\text { Medieval times, i.e.: } \\
\text { Byzantine times (ca. 330-1453 AD) } \\
\text { Egyptian (ca. 824-961 AD) a }\end{array}$ \\
\hline $1200-1900$ & Early modern Egypt: 1517-1867 & $\begin{array}{c}\text { Early and Mid-Modern times } \\
\quad(\text { ca. 843-1205 AD) } \\
\text { Venetian (ca. 1205-1470) }{ }^{b} \\
\text { Ottoman period (ca. 1453-1922) }{ }^{c}\end{array}$ \\
\hline 1900-present & Contemporary times & Contemporary times \\
\hline
\end{tabular}

As a whole, this review paper is organized in eight sections as follows: Section 1 is introductory; Section 2 briefly explains the paper's methodology; Section 3 describes the Physical settings of the studied area; Section 4 deals with the water engineering issues; Section 5 refers to the water and health aspects; Section 6 discusses education and cultures of ancient people; Section 7 addresses the discussion of major issues; and finally, Section 8 provides concluding remarks.

\section{Physical Setting}

In the northeastern corner of Africa, ancient Egypt was located. It was surrounded from the North-East by Canaan and Syria; Nubia from the South; and Libya from the West. The Mediterranean Sea and the countries of southern Europe were to Egypt's North. The Red Sea was to the East (Figure 2).

Egypt was divided into two sections: the southern part is called Upper Egypt, and the northern region was lower Egypt according to the elevation of the ground. The ancient Egyptians thought of Egypt as being divided into two types of land, 'Kemet' means the black land which referred to the fertile land on the banks of the Nile river, and 'Deshret' means the red land which was the empty desert. The natural boundaries of ancient Egypt protected it from aggressors. These borders included to the West Sahara Desert; to the East, the mountainous Eastern Desert and the Red Sea, the Mediterranean Sea ending the swampy Delta to the North and the Cataracts to the South.

Although these borders isolated Egypt, its location was at a crossroads for people, ideas and influence. The Nile river was the single most important element in the geography of Egypt because without the Nile, agriculture would be impossible in Egypt. The Nile flooded annually which was crucial for the production of food for the people. There were three rivers that flowed into the Nile; the Blue Nile, the White Nile and the Atbara, which brought the Ethiopian summer monsoon to Egypt. 

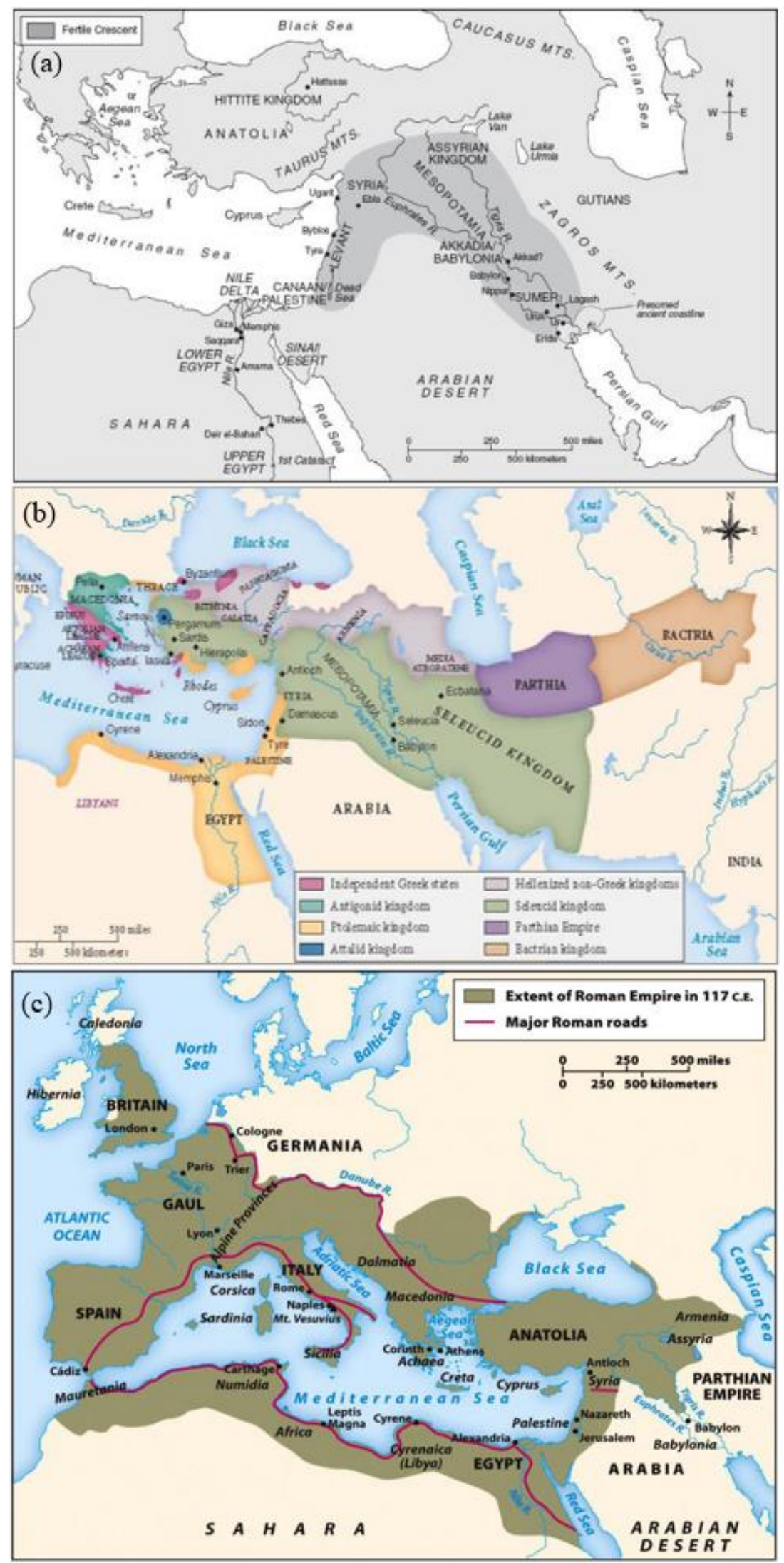

Figure 2. Ancient Egypt and Greece: (a) Ancient Middle East and Mesopotamia period, (b) Hellenistic Kingdoms, 240 B.C.E, (c) The Roman Empire 117 C.E [9]. 
The climate of ancient Egypt was much the same as it is today-a hot, dry desert climate with very little rainfall. Rain and clouds are more prevalent near Alexandria, which is influenced by winds coming off the Mediterranean Sea. Between March and May, a hot, dry wind called the khamasin blows through the desert. The mountainous region of Sinai has the coolest temperatures during the night, due to its elevation. Winter temperatures can drop as low as about two degrees centigrade during the night in some towns [10].

A new scientific study revealed that ancient Egypt struggled with drastic changes in the climate during a period which lasted from ca. 1250 and 1100 BC. During this period, the Middle East North Africa (MENA) region experienced a devastating drought that caused the death of crops and livestock, thus negatively impacting the economy and the citizens of greater Egypt [11].

Though not yet subject to the greenhouse effects of modernity, the world saw more than a few high-altitude volcanic eruptions during this period. Large eruptions released particulate matter high into the stratosphere which in turn shadowed the earth, decreased evaporation and rainfall and reduced seasonal flooding upon which agriculture depends. This effect can last just one season, or a few years [12]. According to Manning's study, "In years influenced by volcanic eruptions, Nile flooding was generally diminished, leading to social stress that could trigger unrest and have other political and economic consequences."

The Greek civilizations were mainly developed in southeastern Greece, including eastern coastal areas of today's Turkey, as shown in Figure 2. However, ancient Greeks were sailors and influenced other Mediterranean regions with establishment colonies, e.g., southeastern Italy and north Egypt (Alexandria region). The climate of ancient Greece was under the influence of marine climate, with warm and dry summers and cold and wet winters [13].

Since pre-historic time, ancient Egyptian civilization flourished in plain areas close to the Nile river, where water for agricultural activities was easily available. On the contrary, Greeks, apart from the Minyan culture at Gla around Kopais lake in central Greece, avoided the establishment of their settlements in the areas with high water availability [14]. Krasilnikoff and Angelakis [15] reported that the locations of most of these earliest Greek cities were in the driest areas (Figure 2). Although the exact reasons remain unknown, we can speculate that the ancient Greeks in prehistoric times preferred the arid climate as more conceivable for human health. Supposedly, such a choice of location offered greater protection against flooding and reduced the spread of water-related diseases. [16].

\section{Water Engineering}

In this section the discussion is focused on water engineering and hydro-technologies in both ancient civilizations such as urban water treatment, water and health, dams, aqueducts, rainwater harvesting, water supply distribution systems, fountains, irrigation, drainage of agricultural land, sanitation technologies including sewerage and drainage systems, baths and toilets, disposal and reuse site and hydropower. Major similarities of the technologies implemented among the two civilizations are considered. Additionally, the basic principles and characteristics of water management sustainability in both civilizations and a comparison of basic water supply and sanitation practices through the long history of the two civilizations are considered and discussed.

In the ancient Egypt civilization, many water technologies and inventions were initiated more than 5000 years ago. Furthermore, Minoans and other civilizations located on the current Crete and Indus valley developed during the Bronze Age (ca. 3200-1350 BC). They established water structures, such as aqueducts, cisterns, filters, settling pools, rainfall-collecting systems, ceramic pipes for water supply and sewage, and the drainage systems [17]. The communication of Minoans with Egypt intensified from the period of the first palaces (ca. 1900-1700 BC), probably favoring knowledge transfer in water, wastewater and storm water management practices [18]. 


\subsection{Water Lifting Devices for Irrigation}

The shift to lift irrigation was well underway during the 18th Dynasty and was effective from Roman times [19]. Sometime after 1500 BC, the ancient Egyptians began lift irrigation with the shadouf, which was already in use in Mesopotamia for irrigating small plots. This device allowed the irrigation of crops near riverbanks and canals during the summer. The shadouf had a bucket and rope attached to the one end of a wooded arm with a counterbalance at the other end of the arm as seen in Figure 3. This device typically lifted water up to $1.5 \mathrm{~m}$. One shadouf could irrigate approximately 0.12 ha of land in $12 \mathrm{~h}$.

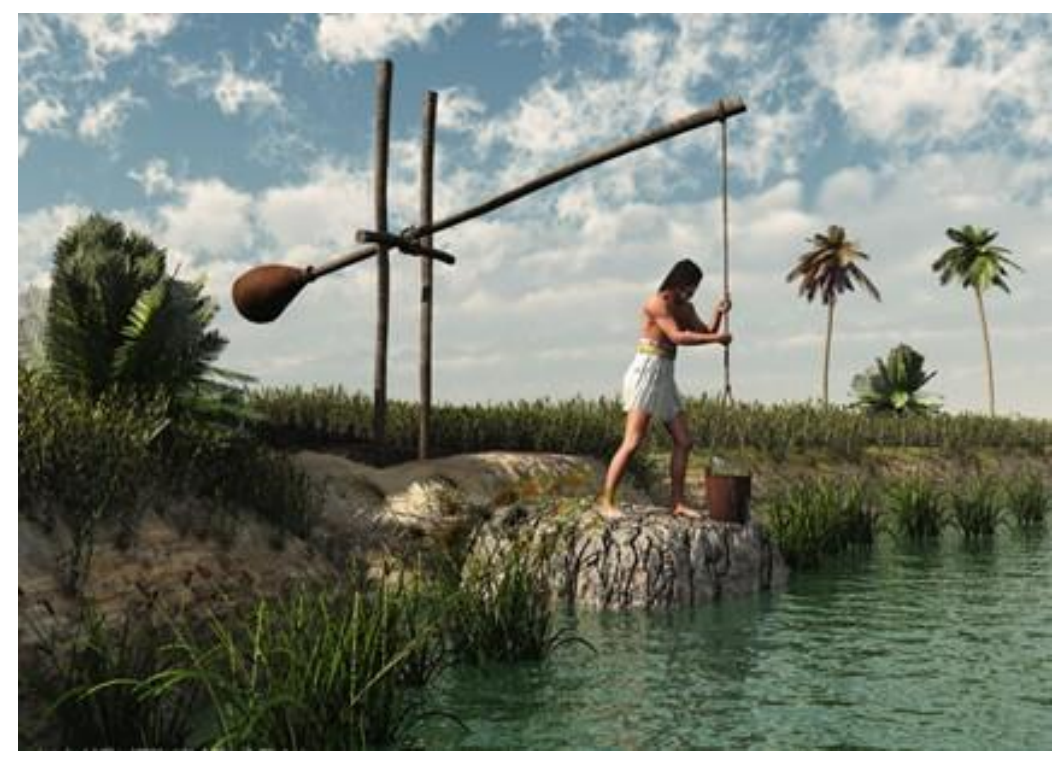

Figure 3. Shadouf for lifting water in ancient Egypt [20].

Haldane and Henderson [21] reported that the shadouf is a man-power apparatus which from ancient time has been used in Egypt in lifting water from the Nile river or artificial canals for local irrigation farms. They investigated the lifted distance and energy consumed for using shadouf. They found that the bucket holds about $27 \mathrm{~kg}$ of water when nearly full, as in the lift, and is raised 11 feet 6.5 to 8 times a minute. Therefore, the work done in lifting the water is about $600 \mathrm{~km} / \mathrm{h}$. Two men, working alternately for about an hour at a time, are employed on each shadouf, and each man works for a total of about $6 \mathrm{~h} / \mathrm{d}$. Therefore, the work per day is about 700 foot-ton. The corresponding amount of energy liberated in the body is therefore equivalent to about 417 calories in an hour.

At the same time, Minoans in the eastern Crete (e.g., Itanos, Zakros and Palaikastro) discovered shadouf and constructed groundwater wells (of depth up to $20 \mathrm{~m}$ ) [11]. It is believed that the Minoans used the shadouf in the Meso-Minoan period (ca. 2100-1600 BC). It was widely used in Greece during the Classical and Hellenistic periods [22].

Paddle-driven water-lifting wheels had appeared in ancient Egypt by the 4th century BC [23]. The Egyptians are credited with inventing the water wheel known as sakia or noria with attached pots. The water wheel comprised from water compartments and a bucket chain, which ran over a pulley with buckets attached to it (Figure 4). The compartmentalized water wheel invented in ancient Egypt in the late 4th century BC, in a rural environment, and spread in other areas of North Africa [21]. 

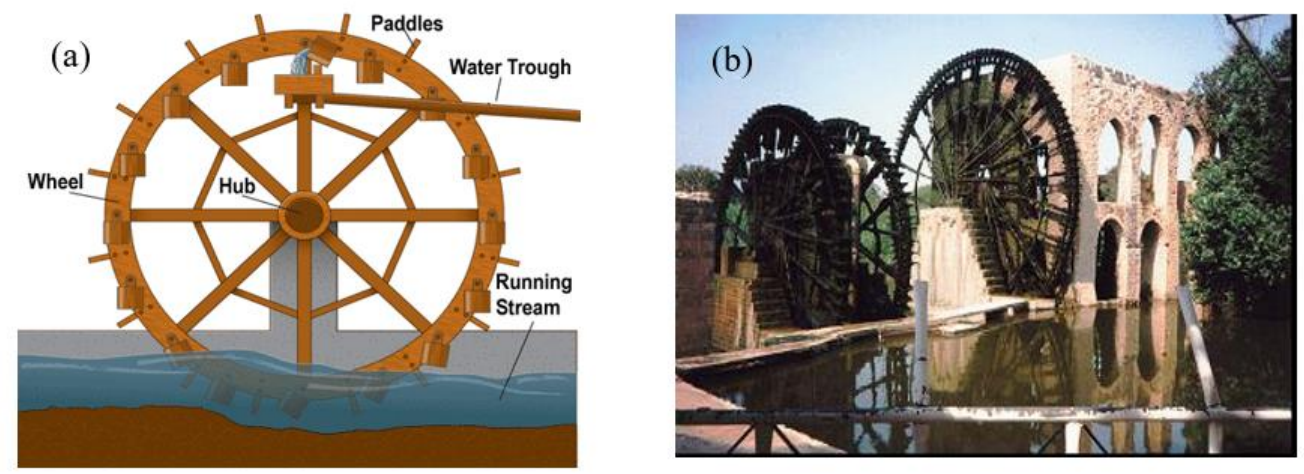

Figure 4. Water wheel (noria): (a) parts and (b) in Hama on Orontes River in Syria [21].

According to Oleson [24], the compartmented wheel and the hydraulic n preceded sakia's invention, which was carried out about a century later. On the other hand, De Miranda [25] reported that many sources based on archaeological evidence showed that, most probably, the earliest waterwheel was found at Fayoum in Egypt dating from the 3rd century B.C. This is supported by Vullo [26], stating that the oldest archeological evidence of a water wheel in the form of a sakia was found in Fayoum. In addition, in the Peri Alexandreias by Callixenus, there is the first mention of the existence of a wheel which corresponds to sakia used at Alexandria during the reign of Ptolemy IV (221-205 BC). Subsequently a fresco from the 2nd century BC, representing a compartmented Sakia, has been found in Alexandria.

Many types of wood can be employed in manufacturing sakia, depending on local availability. In Egypt, for instance, the trees used are acacia and tamarind. An example of wooden sakia in Egypt is shown in Figure $4 \mathrm{~b}$. These devices always transform right-to-left, due to a natural tendency of humans to use the right hand. In fact, the man pushes the animal to move to the left [27].

From the third century BC and during the Hellenistic period, a new water technology innovation was developed around knowledge centers, such as Alexandria in Egypt. Many new water lifting devices were developed based on the endless screw of Archimedes shown in Figure 5. The hydraulic endless screw known as Archimedes screw (287-212 BC) was described by the Greek mathematician and engineer, but not necessarily invented by him. It is still today used for pumping wastewater and granular materials.

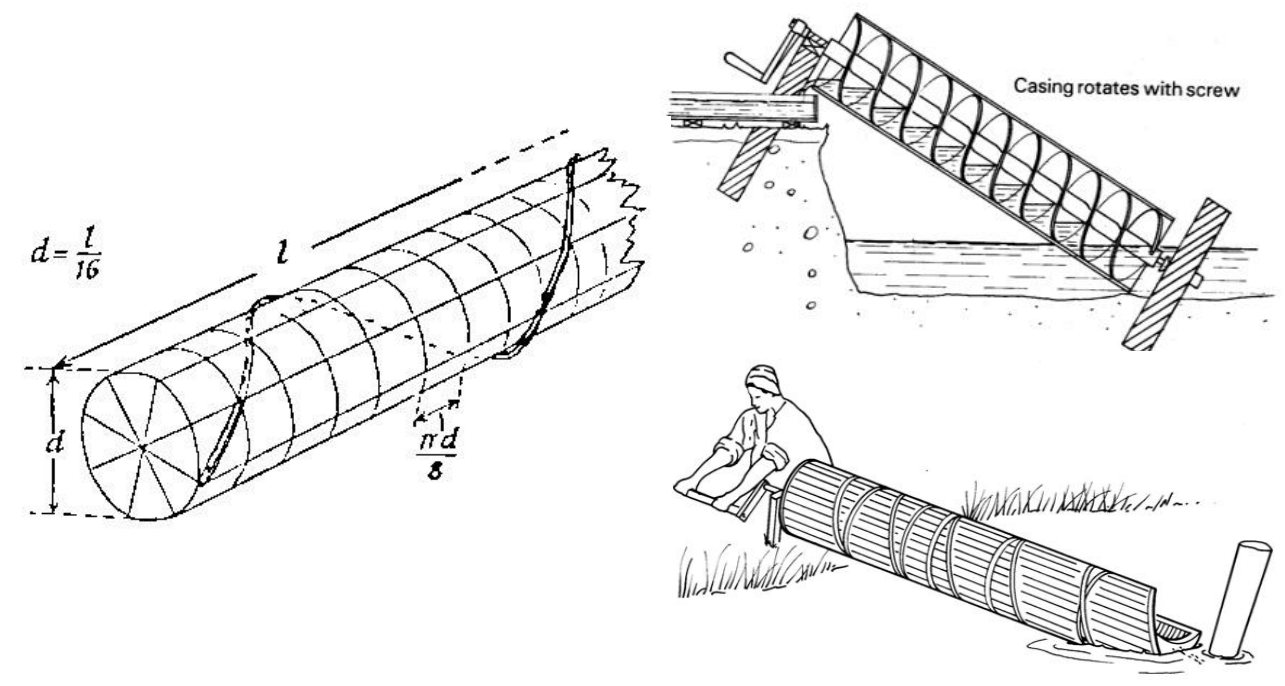

Figure 5. The Archimedes screw, as described by Vitruvius, and similar devices [22].

According to Lazos [22], ancient historians, e.g., Vitruvius (ca. 80-20 BC), Philo of Byzantios (ca. 280-220 BC) and Philo of Alexandria (ca. 20 BC-50 AD) who lived mostly in Alexandria, considered 
that the screw was invented by Archimedes. These devices, when used for water lifting, require energy that can be supplied by either human or animal force or by the water current itself.

At the same time, the pump known as Ktesibius in Alexandria was invented by the ancient Greek mechanical engineer Ktesibios (ca. 270 BC) shown in Figure 6. It was described in the first century BC by the Greek scientist Hero of Alexandria (ca. 10-70 AD) in his treatise Pneumatica and later by Vitruvius in his work De architectura [21]. Ktesibios described one of the first force pumps for producing a jet of water, or for lifting water from wells. Furthermore, Heron introduced the aerophile, which is known as Heron's engine. It was the first recorded steam engine. It was invented about two thousand years before the industrial revolution. Tassios [28] supports the idea that the Ktesibios pump was mechanically linked to the aerophile to form the first steam water pump on earth.

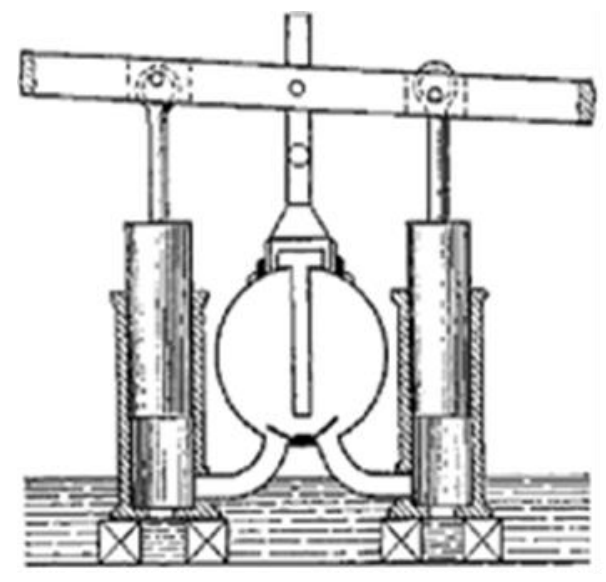

Figure 6. Ktesibius force pump, as described by Heron, with adjustable nozzle [29].

\subsection{Water Management for Irrigation}

The first evidence of water management for irrigation was the mace-head of King Scorpion (ca. 2725-2671 BC). This has been associated with the ceremonial opening of the first embankment for the regulation of water and its transfer to the fields or construction of a new canal [30]. Additionally, the main parts of the mace-head have been interpreted as an irrigation activity supervised by the King himself. Overall, the mace-head has been considered as an evidence of the ability of the ancient Egyptians, about 5000 years ago, to manage water for agricultural purposes.

Another document of the transition from natural to artificial irrigation is provided by the lower part of the mace-head depicting a waterway bifurcating to two irrigation channels. The King is also depicted, holding a large hoe, together with attendants carrying a fiber basket and a broom, while other people are working on a canal. These have been interpreted as evidence that the transition to artificial irrigation had been completed by the end of the Predynastic period. Apart from irrigation purposes, canals were also built to relieve water traffic and to drain marshes.

The artificial irrigation is considered to have been established by the 1st Dynasty in Egypt [19]. Artificial flooding and draining were developed by using sluice gates and water contained by longitudinal and transverse dikes. As a result of spreading of the artificial irrigation, larger areas for annual croplands were available. Moreover, more water was available after smaller floods, whereas second and third crops were allowed in some basins. This form of water management, called basin irrigation, consisted of a network of earthen banks, some of them built in parallel to the river and some other perpendicular forming basins of different size. Artificial basin irrigation was based on the flooding of the Nile plain that began in early August. The flood was divided into basins ranging in size from 2000 feddans $\left(1\right.$ feddan $=4200 \mathrm{~m}^{2}$ ) in the upper part of Egypt to 20,000 feddans in the Nile Delta [31]. The concept of basin irrigation is illustrated in Figure 7. The bed level of the feed channel was in the middle of the low Nile level and the ground had a natural downward slope smaller than the Nile slope. 


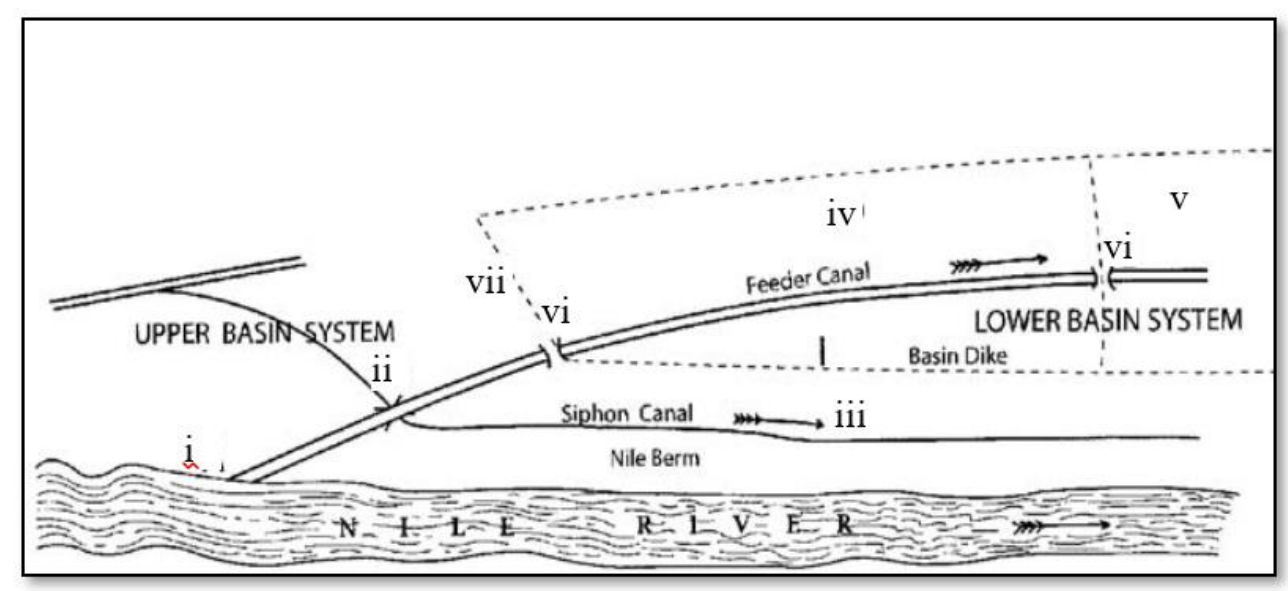

Figure 7. Plan of basin irrigation: head of basin canal, (i) siphon of siphon canal, (ii) high land under sorghum, (iii, iv) basins, (v, vi) regulators, (vii) transverse dike, (viii) longitudinal dike [31].

Floodwaters reaching into the basins saturated soil whereas the redundant water drained off to a lower gradient basin or to a canal (Figure 7). When draining process ceased crops were planted onto basin. The first known man that first developed a basin irrigation project was King Menes, the founder of the first dynasty in ca. $3100 \mathrm{BC}$. The basin irrigation was carried out on a local scale as opposed to central basin management that was on a national scale.

Ancient Egyptians used water diversion constructions such as dams to control floods of the Nile. The Al-Kafara dam is the oldest known such a dam, constructed during the Third or Fourth Dynasties of Pharaohs (between 2686 and 2498 B.C.). Its location was $30 \mathrm{~km}$ south of the current Cairo, between "Wadi Al-Hof" and "Wadi Al-Garawi". The dam capacity plan is believed to be $600,000 \mathrm{~m}^{3}$ of water. Its construction needed the excavation and transport of approximately $100,000 \mathrm{~m}^{3}$ of rocks $[32,33]$

The dam was 107 to $113 \mathrm{~m}$ in crest length and 11 to $14 \mathrm{~m}$ in height (Figure 8). It consisted of two masonry shoulders supporting a central core of sand and gravel. The core consisted of 60,000 tons of earth and rock-fill [34]. The downstream wall was about $37 \mathrm{~m}$ wide, the upstream wall about $29 \mathrm{~m}$ wide and they contained around $2900 \mathrm{~m}^{3}$ of material mass. These upstream and downstream walls were constructed from limestone ashlars. Each stone was roughly $30 \mathrm{~cm}$ high, $45 \mathrm{~cm}$ wide, $80 \mathrm{~cm}$ long and $23 \mathrm{~kg}$ [35]. Due to the erosion of the downstream face of the dam and lack of a spillway, it is believed that a flood destroyed it. While the crest of the dam sloped towards the center, which the engineers perhaps used it as a spillway. However, as the top of the dam was not beheaded, it was not protected from floodwater that would overtop.

For water level monitoring of the Nile river, ancient Egyptians established many indicators for recording water level every year. Indicators, at least 20, were placed along the river allowing records for the maximum level flood of each year. The early version of this monitoring system includes marked flights of stairs, used for thousands of years, shown in Figure 9 [33]. 


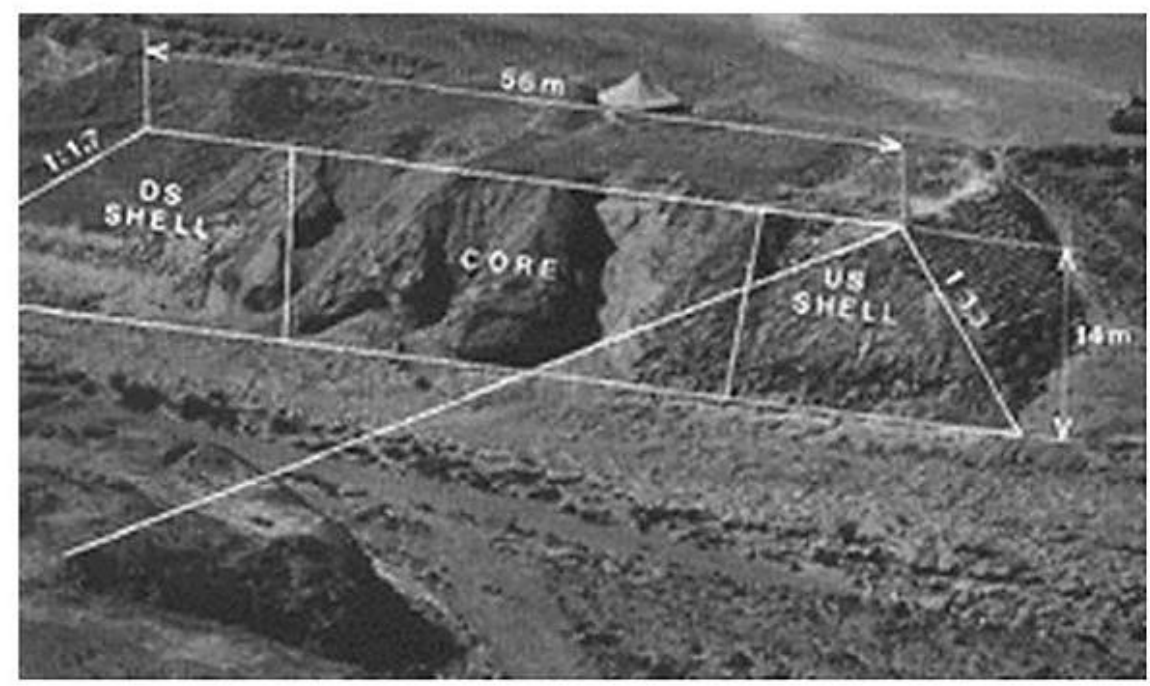

Figure 8. A photo for Sadd-Elkafara dam ruins and sketch for its cross-sectional dimensions [36].

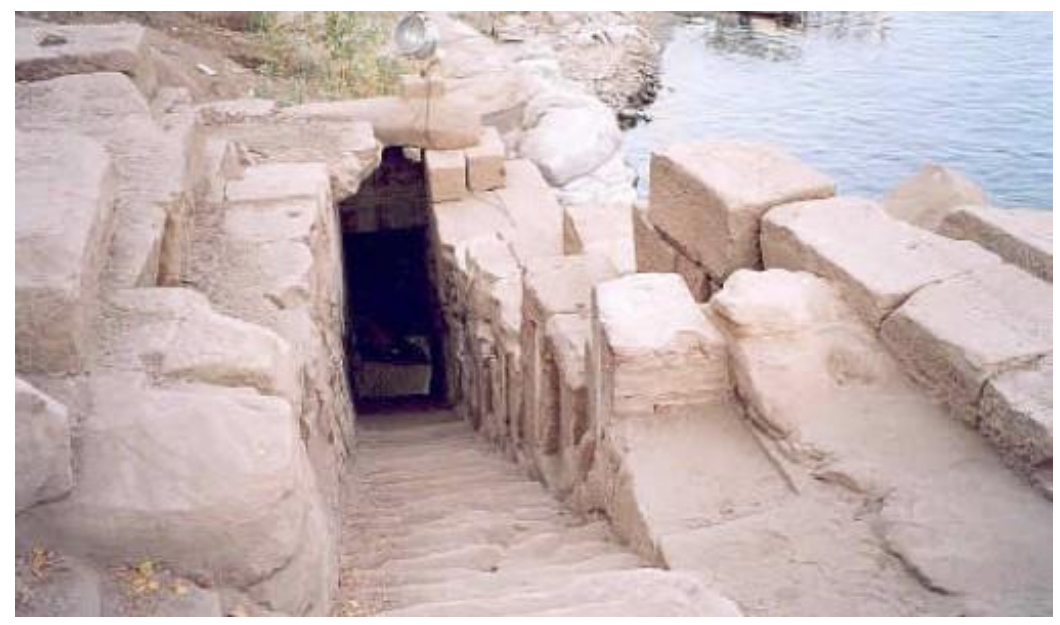

Figure 9. Water level indicator on Elephantine island in Aswan [37].

On the contrary to the ancient Egyptians who developed large-scale irrigation projects, the ancient Greeks developed rather small-scale projects since early Minoan times. An example is the integrated water management system in the valley of Choiromandres on the southeastern edge of the Zakros area (located at the eastern end of Crete), covering an area of around 7.5 ha [38,39]. The Minoans regulated the flow of streams, through a system of dams, to supplement fields with water and to prevent soil erosion of arable lands (Figure 10). The first attempts have been attributed to the Paleopalatical period (ca. 1900-1700 BC) when megaliths were used to build dams at sizes that may have exceeded the $3.10 \mathrm{~m}$ height and a length of $27 \mathrm{~m}$ [38]. There is a dam that was rebuilt at the top during the late Classical and Hellenistic periods [38]. At the lower end of the ravine, there was a permeable barrier to control the flow of water and use it for irrigation. Other similar irrigation projects at that time are found in the Pitsidia and Pseira in southeastern part of Crete. 


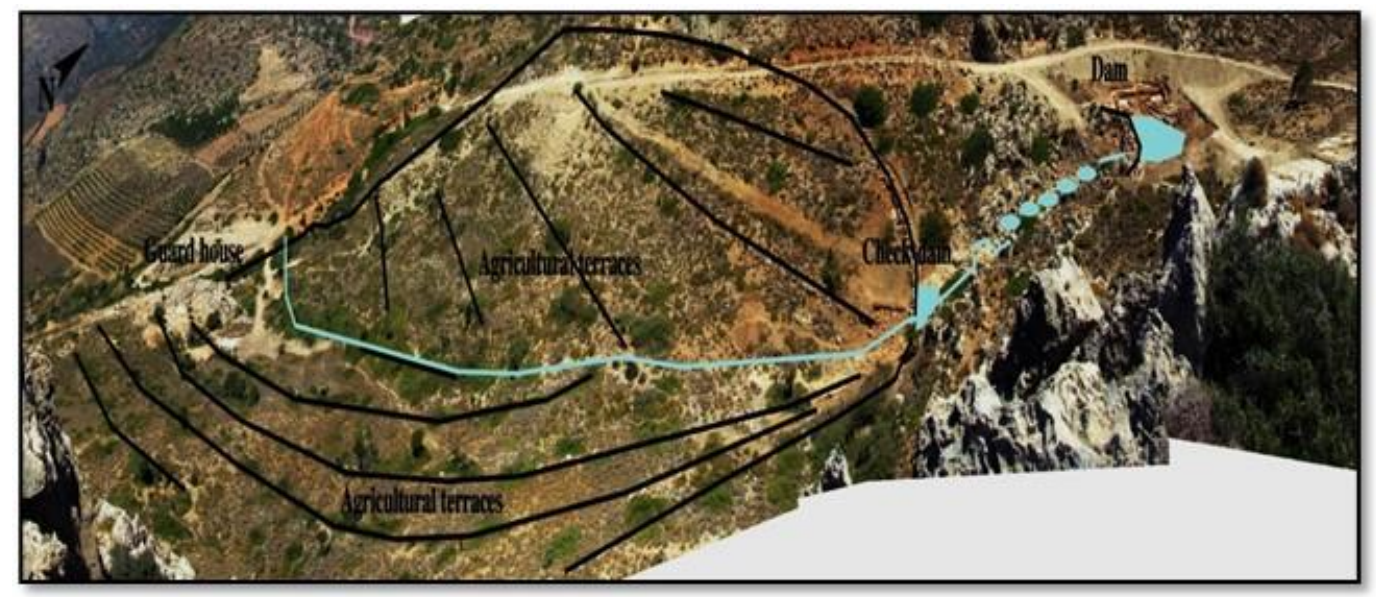

Figure 10. The main dam, the check dam, and the irrigated agricultural terraces in Choiromandres [39].

During Classical and Hellenistic periods similar irrigation practices were used in rather small-scale irrigation fields. Hitherto, scholars have convincingly argued that the kepos (i.e., the Greek garden), was developed during the Bronze Age as a small cultivated and irrigated area [40]. Theophrastus (371-287 BC) describes how gardeners cultivated different plant species, such as potherbs, vegetables, herbs and flowers. Thus, the kepos was potentially established to cultivate a wider range of crops than modern gardens $[40,41]$. Undoubtedly, in the Classical and Hellenistic periods, the term kepos referred to a small-size place, often located at or near the residence location of households (oikos), where crops, water and manpower co-existed.

\subsection{Agriculture}

Due to their developed basin irrigation, ancient Egyptians are considered as the first people who were able to farm large-scale land. Because of their agricultural experience, they were able to grow main grains, such as barley and wheat, needed for food as well as other crops, such as flax and papyrus used in industry activities (Figure 11a). In addition, orchards and gardens were developed beside to the field planting in the floodplains. During the New Kingdom, Egyptians started planting olive, carob and apple. Then, in the Greco-Roman period, they knew planting peaches and pears. Ancient Egyptians depended on plants not only to produce food, but also, they used them for manufacturing medicine and clothes [42].
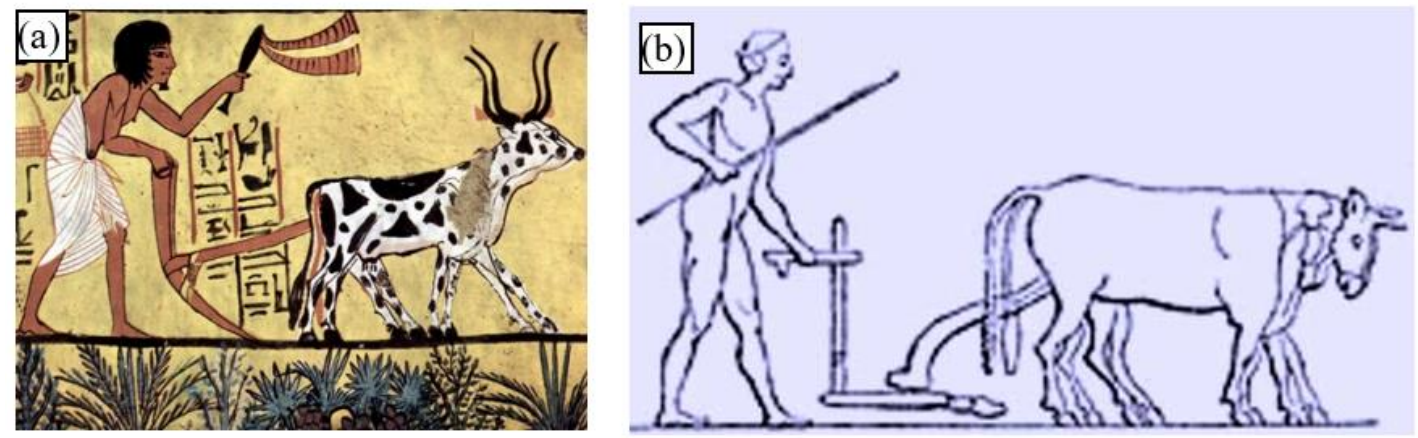

Figure 11. The original plows: (a) The ox-drawn plow used by Egyptians [42] and (b) that known as plow of Hesiod used by ancient Greeks [43].

Ancient Egypt developed innovations to help cultivate the land. Among the many inventions or innovations of the ancient Egyptians was the ox-drawn plow (Figure 11a). The ox-drawn plow was designed in two gauges: heavy and light. The heavy plow went first and cut the furrows while the lighter plow came behind turning up the earth. Once the field was plowed, then workers with 
hoes broke up the clumps of soil and sowed the rows with seed. To press the seed into the furrows, livestock was driven across the field and the furrows were closed.

On the other hand, in Greece, for nearly four centuries that passed between Hesiod and Xenophon, no improvements can be found in agriculture. Bronze was used for farm tools and weaponry. Tools remained mediocre and there were no inventions to lighten the work of either man or animal. Minoan were imported obsidian stones from Phylakopi in the Aegean island of Melos, which due to its hardness was used for constructing several tools including those used for cultivating the land. For almost four centuries, the state in which Greek agriculture was practiced did not change. The same ordinary tools which existed before continued to exist in the same way. No attempts were made to produce any such new tools which could ease off the labor of the ancient Greek farmer [44].

The agricultural tool used to plow the land changed greatly when at the begging of the Archaic period the plow of Hesiod (flourished ca. 700 BC) was discovered [43]. It is shown in Figure 11b. It was also the simplest tool that man used to cultivate the land, and, in fact, it was used to a great degree. It was the main instrument with which the first cultural revolution took place, the agricultural revolution in the 12th century BC, during which man ceased to be a wandering forager, settled in a specific area and created organized settlements and cities. A type of plow, the so-called gel plow, was already mentioned in the Iliad and the Odyssey.

Regarding the cultivated crops by ancient Greeks living in the south country, they cultivated more or less the same crops as today, i.e., cereals (mainly barley), olives for olive oil production, grapes for both table grapes and vine and vegetables, e.g., cabbage, onion, garlic, lentils, beans, sage, mint, thyme, savory and oregano [45]. Note that even if the ancients Greeks were aware of the better nutritional value of wheat, the growing of barley was less demanding and more productive. Moreover, the ancient Greeks cultivated some fig and almond.

\subsection{Aqueducts}

The construction of gravity-fed aqueducts was not possible in Ancient Egypt, as water resources at higher elevation were not available [8]. As an exception, Achaemenid Persians used an aqueduct or quant to supply water about $200 \mathrm{~km}$ to the west of the Nile valley, whereas the Kharga Oasis. By about 525 BC, a qanat was built as a series of the vertical shafts, linked by a slightly sloping passageway [46]. One sample of these vertical shafts in the Kharga Oasis are shown in Figure 12a. A qanat taps into subterranean water in a manner that efficiently delivered large quantities of water to the surface without the need for pumping: The water drains by gravity, typically from an upland aquifer. The Bahariya Oasis is also a good example of adopting the qanat system.

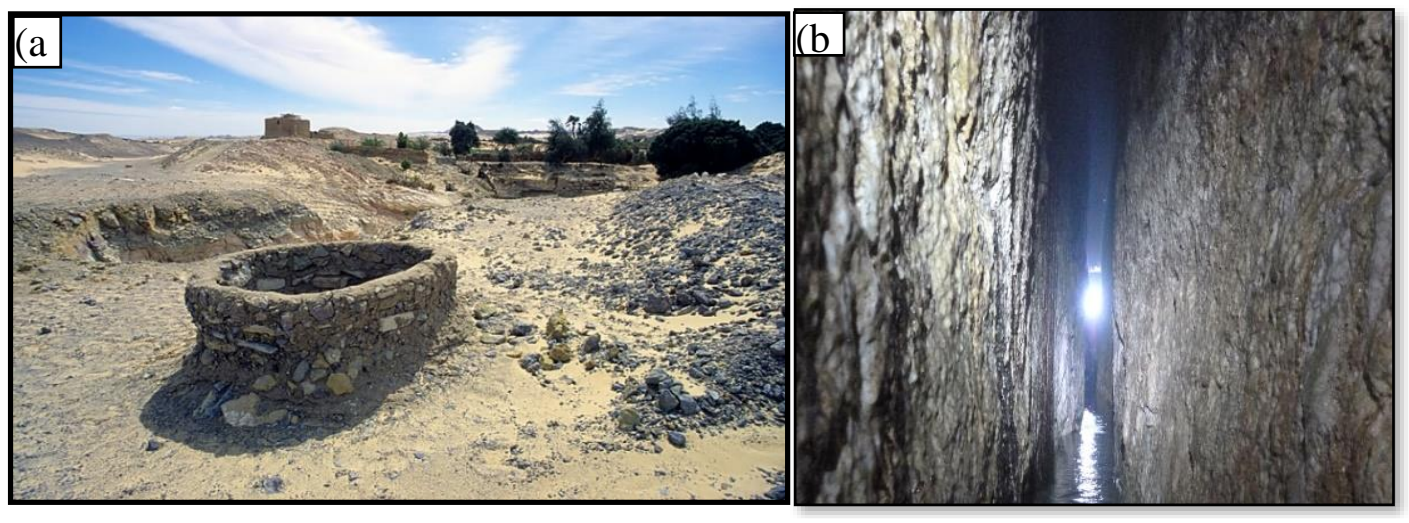

Figure 12. Underground aqueducts: (a) A vertical shafts of Qanat system in the Kharga Oasis, Egypt [46].

(b) The tunnel of the Peisistratian aqueduct in Athens (with permission of P. Defteraios).

In a large scale, there are many sites showing remains of the qanat boundaries [47]. In Wadi EI Gudeirat in the northeastern part of Sinai, there is a spring called Ain EI Gudeirat. It originates from 
the lowermost part of the highly fractured limestones at a daily rate of $1500 \mathrm{~m}^{3}$. The spring water flows in a small aqueduct or channel constructed centuries ago and is used currently to irrigate olive trees and as a source of water for the local villages [48].

Moreover, open and underneath causeways or aqueducts are common to all pyramids that were built by pharaohs close to the banks of the Nile. Aqueducts transferred Nile water into the base of the pyramid. They are connected to the base of the pyramid and the Nile bed with a large opening to the sky structure and huge stone doors that open and close inside the Nile river. Inside the Giza pyramids, there were the openings and passageways to an enormous underground cavern with the size of a football field under the pyramids. There were also shafts and aqueducts. When the Nile flowed beside the pyramids, the opening here was deep under the surface of the river, and the enormous chamber would fill up with water, directly underneath the pyramids [49].

The aqueduct was called as quant or aflaj in the near Middle East [50]. The key difference between an aqueduct tunnel and a qanat is that the latter is completely a water collecting system dug at or under groundwater level while the aqueduct tunnel mostly conveys trapped water elsewhere [51]. Qanats can be up to $18 \mathrm{~km}$ long and are usually dug close to their terminus, mostly for agricultural irrigation and for domestic water supply [51,52]. The technique of the qanat building has stayed nearly fixed for 2000 years. The first process for the qanat construction is the digging of the vertical shafts and then they are connected by the underground channel [53].

At the same time (ca. 6th-5th century BC) the Peisistratian aqueduct in Athens, a truly gigantic technical work was implemented by Peisistratos, as genuine tyrants, in order to offer water to the Athenian people. It is an underground aqueduct, which consists of tunnels and wells up to $14 \mathrm{~m}$ deep, very similar to qanats (Figure 12b). It is definitely a huge technological achievement by which water from Hymettos mountains were transported to a distance of $10 \mathrm{~km}$ in the Athens center. It is still today someway in operation since water from it is used to irrigation the National Garden located in the center of Athens [54].

Similar technology which were developed in the Archaic period were used for many centuries, especially during the Hellenistic and Roman times, for water supply and irrigation purposes [55]. Aqueducts in Greece generally received free surface flow; however, the scientific insights in understanding of hydrostatics, occurred during the Hellenistic period, provided by Archimedes, Hero of Alexandria, Ktesibius, and others, allowed Greeks and Egyptians to develop inverted siphons at large scales (lengths of kilometers, hydraulic heads of hundreds of meters) [16]. These siphons, made of terracotta or stone pipes, allowed to convey water across valleys in aqueducts in several cities, such as the Alexandria that was supplied with the water of Nile. There are also examples in Acharnian in Athens, Polyrrhenia in western Crete, Hadrianean in Athens, and the city of Rhodos in the inland of Rhodos.

\subsection{Treatment of Urban Water}

In prehistoric times, people searched for pure water supplies. In that time, the only available water quality standards were the natural properties of water such as taste, temperature, smell and appearance. Using chemicals to purify water was not available to ancient people. The Egyptians first discovered the principle and the basis of coagulation (after ca. $1500 \mathrm{BC}$ ). They used a chemical alum to settle suspended particles [56]; In the walls of tomb of Amenophis II and Ramses II, there are pictures of this technique. The Egyptian purification device is shown in Figure 13a. This device caused settlement of "pollutants" of the water and purified water was siphoned off and collected for reuse.

Egyptians also adopted natural substances such as herbs including Amla and Vetiver for water treatment. These herbs were mixed in water for purification purposes. They used natural products and materials such as plant seeds and some stones such as quartz crystals, garnet and peals for water purification [57]. 


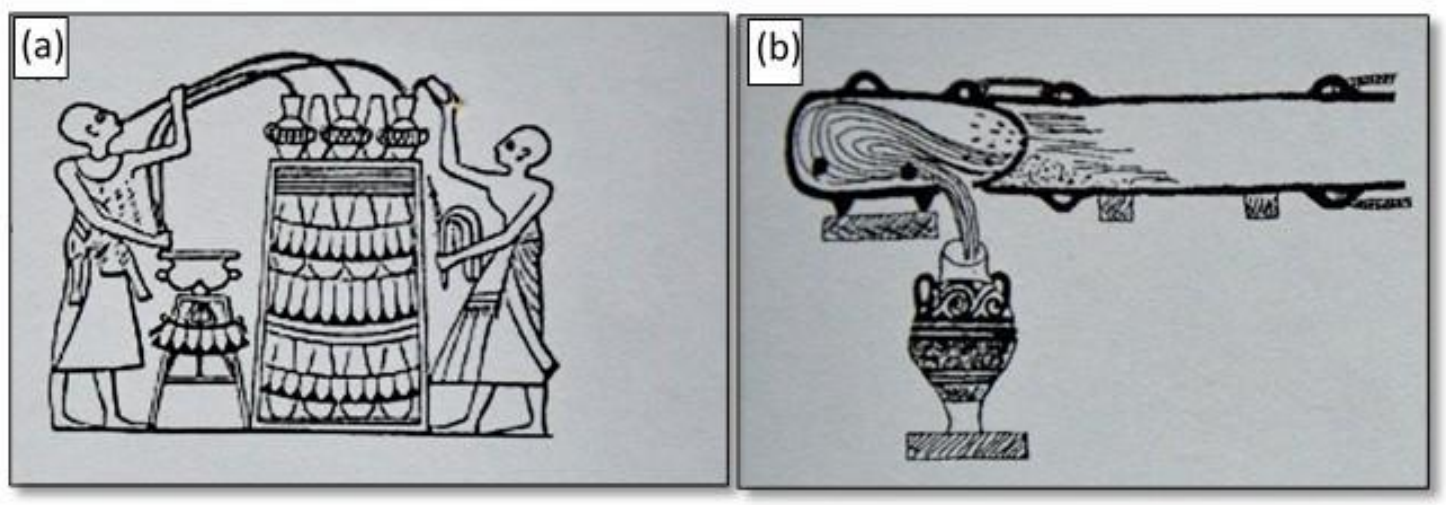

Figure 13. Bronze Age water purification devices: (a) Egyptian clarifying device [58] and (b) Minoan water treatment device [59].

Later, in the Middle Bronze Age, in Crete, many archaeological and other sources reveal that there was a "cultural explosion" unmatched in the history of other ancient civilizations. A remarkable indication of this is exhibited in using advanced techniques for the urban water management in Crete at that time.

From the beginning of the Bronze Age, devices for water supply used in villages, cities, and particularly in palaces, were one of the prominent features of the Minoan civilization (ca. 3200-1100 BC). It is truly wonderful to know that Minoan engineers in that time provided many water quality modification techniques for supplying suitable domestic water. Thus, according to Dafner [59], a strange, oblong device with an opening in one of its ends was used to treat domestic water (Figure 13b). The device was assembled in an analogous way and with the same material as the ceramic water pipes. Spanakis [60] considered this device as a hydraulic filter which was probably connected to a water supply reservoir by a rope passing through its outside holds. Its operation relied on local, high speed, turbulent conditions in order to continuously clean the porous surface thus allowing the continuous flow of filtered water to the jar. For cleaning purposes, after extensive solids accumulation, it was possible to release it from the pipe end by loosening the rope in the holes.

In addition to the ceramic filters, ancient Greeks used sedimentation tanks and sand filters for treatment of the potable water since prehistoric times. In order to eliminate the suspended impurities from the water as sediment, a small cistern of stone was used before its storage in the main cistern in the Minoan village Tylissos [61]. A typical cylindrical basin used in this process is shown in Figure 14a [62]. In settlements, where rainwater was collected from the yards and roofs of buildings (harvesting), for example in Phaistos palace, rainfall water was collected and stored in cisterns [62]. Special care was taken with the hygiene of water collection by filtering the water in coarse sandy filters before it flowed into the cisterns (Figure 14b). Since the Classical period, the continuous quest for clean water led Greeks to the further improved water treatment through the development of many types of filters such as coal, cloth and ceramic filters [62].

Alexandria's development had always been dependent on the quality of its waters. As it has already been mentioned at early times, Alexandria's water supply was carried out through the Nile river of $12 \mathrm{~km}$ apart. The Nile water was stored in hundreds of cisterns through channels (Figure 15). Dunn [63] reported that 500 cisterns are known out of over two thousand that should be existed. Sedimentation cisterns were probably used at that time similar to those used by Greeks centuries before. 


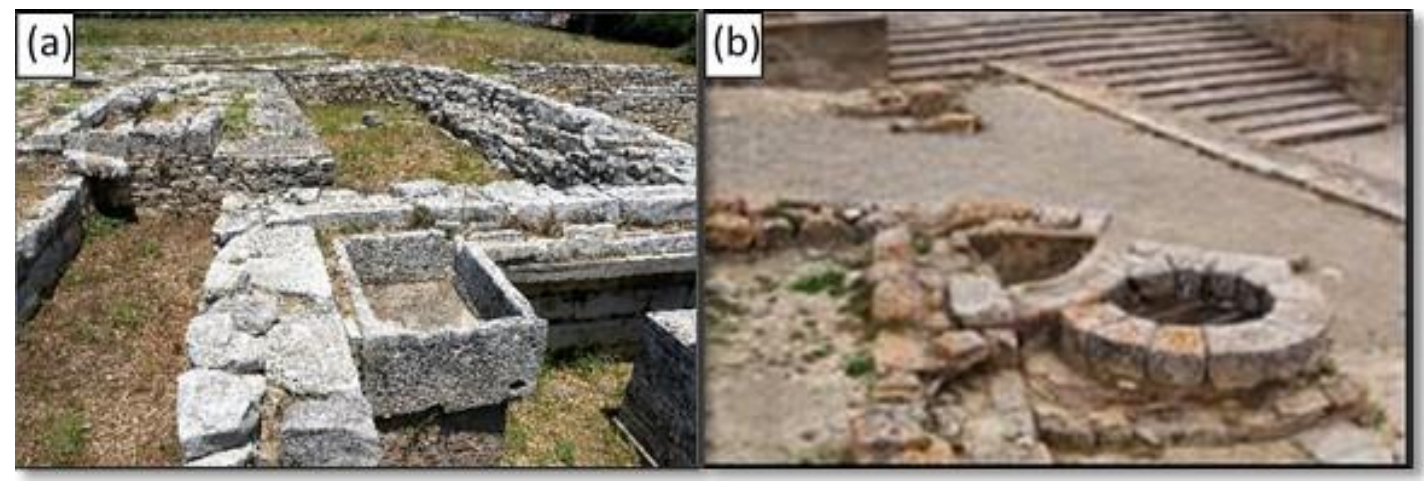

Figure 14. Water treatment devices in Bronze Age: (a) Small stone-made cistern used as sedimentation of suspended solids in Tylissos and (b) special cistern with coarse sandy filter in Phaistos palace [60,62].

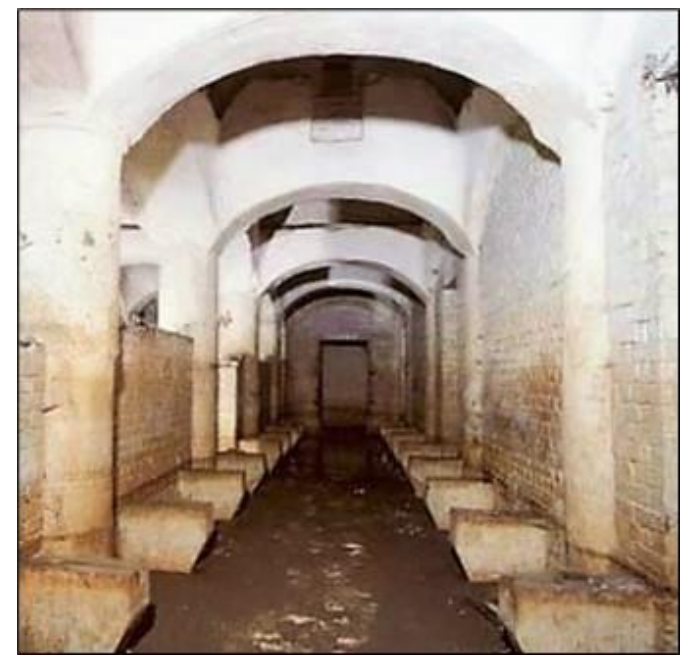

Figure 15. One of the thousand Alexandria's cisterns [63].

Later on, during the "Alexandrian Wars", Caesar discovered the importance of water quality. After fortifying and entrenching himself in the great theater, the Alexandrians had made the wells they depended on unusable by contaminating them with sea water due to sea water intrusion [63].

\subsection{Water Supply and Drainage Systems and Other Purgatory Infrastructure}

Ancient Egyptians established water supply systems for villages far from the Nile by transporting the water via a carrier system by manpower or digging wells. Furthermore, for the remote areas in desert, the distribution of water supply points on the road was essential. It was decided that cisterns and wells would be constructed, which were technically quite simple at the beginning, but were updated progressively with the passage time [64].

In order to protect the health of the people and the environment, the issues of proper sanitation were given due attention. The ancient Egyptians apparently had a viable sanitation system, however, the sanitation level varied among inhabitants being dependent on the social status of individuals. For example, in the ancient Egyptian city of Herakopolis (ca. 2100 BC), the wastes were not properly managed and were left into the streets increasing health risk for inhabitants. By contrast in other places with higher status, like the elite and religious quarters, wastes were usually transferred to locations outside the living areas, such as rivers protecting people from waste-related diseases.

The bathrooms of Egyptians were usually built near their houses. In the New Kingdom, the gentry had small bathrooms in their homes. In the larger homes, there was a bathroom next to the master bedroom, consisting of a stone tub that the person stood in and had water poured over them. By contrast, there is no evidence that the homes of the common people had bathrooms. Actually, a bathroom was 
usually a small room with a slab of limestone located in a corner. Around $2500 \mathrm{BC}$, the Egyptians were familiar with drainage, emphasizing the importance of water in sacred rites of purification and those that influenced the burial of kings [65]. According to their religion, death was simply a transition from one state of life to another. If the living needed food, clothing and other necessities of daily life, so did the dead. Thus, it is not surprising that archaeologists have discovered bathrooms in some tombs. Example of this are the temple of King Suhura at Abusir and the tomb of Osiris [65].

In Prehistoric Greece, sewerage and drainage systems were employed since the establishment of the first well-organized settlements in the early times of the Bronze Age [37]. Evans [66] stated that "Throughout the history of humankind, one of the most remarkable and advanced achievements is the water supply and sewerage systems of the Minoan period."

In the palace of Minos at Knossos, there were sewage and rainwater drains, passing underneath most of the palace [67]. Furthermore, collected water from the roofs was sent to the toilets of the last floor. Generally, all sewerage and drainage systems were built of dressed stones large enough for cleaning and maintenance [68]. There were also airshafts that were used to ventilate sewers [69]. In Phaistos similar to Knossos drainage and sewerage systems were built. The most advanced ancient Minoan drainage and sewerage system seems to be that in the Vila of Hagia Triada, a system that was admired by several visitors, including the Italian writer A. Mosso [70]. He noticed the perfect drains/sewers and recorded the incident by saying: "I doubt if there is other case of stormwater drainage system that works 4000 years after its construction". Additionally, Gray [71] said, "you can enable us to doubt whether the modern sewerage and drainage systems will operate at even a thousand years. Therefore, the Minoan plumbers planned and constructed projects that functioned for centuries, unlike today, when if a project operates well for 40-50 years is considered satisfactory" [16].

\subsection{Rainwater Harvesting}

Rainwater harvesting was practiced in the past to provide water supply for house applications. In the city of Alexandria, Egypt, ancient people gave special care to the collection and utilization of rainwater. They constructed isolated small cisterns for rainwater collection. Cisterns having regularly 0.30 to $0.40 \mathrm{~m}$ in depth functioned as a rainwater collection basin. The shallow trenches observed along its walls enabled the flow of rainwater to the cistern. The type of these household small cisterns, which catch rainwater, provided a solution to the issue of water supply, storage, and treatment as well, due to its function as a sedimentation cistern [72]. These old cisterns were very common in many regions in the Mediterranean. They often were dug in the rock, in the shape of a bell or a bottle, with or without a neighboring pipeline. Such hydro-technologies were also practiced in ancient Greece since the Minoan Era [73]. The small capacity is a general characteristic of those early times. For instance, a plethora building during the Classical and Hellenistic periods had a cistern for collecting and storing rainwater. These technologies were further improved and increased their scale reached to thousands of $\mathrm{m}^{3}$ in Roman times, and the private indoor cisterns were replaced by large public collective cisterns $[73,74]$.

\section{Education and Culture}

The ancient Greeks greatly appreciated Egyptians and their country and saw in it a mysterious land, very fertile with hidden wisdom. At one point, i.e., in Alexandria, which increasingly resembled a cosmopolitan city, they united all the different scientific doctrines originating in the East. Thus, one universal critical mass of scientific knowledge with emphasis on medicine was created.

At that time, in parallel to medicine uprising, Egyptians had an extraordinary command of science and technology. For example, the ancient Egyptians invented paper and ink, cosmetics, the toothbrush and toothpaste, and other household goods. Moreover, they developed knowledge and skills in a wide range of scientific areas and human activities, including construction, agriculture, architecture, astronomy, art and literature. This continued until, by the time of the Ptolemaic Dynasty (ca. 323-30 BC), 
the last to rule Egypt before it was annexed by Rome, when they had created one of the most impressive cultures of the ancient world.

By that time, the "Alexandrian School of Mechanics" evolved. The term "School" is not annotated to a particular alma matter, but rather a group of mechanics who did not live at the same place or time, but rather during the Alexandrian era. One of the "School" members was Archimedes who lived in Syracuse in Sicily. Some of them of course lived in Alexandria and their common characteristic was their search and innovations in Mechanics and, in particular, in Hydraulics [75]. At that time, advanced and prodigious hydraulic works were innovated. Their innovative ideas developed road maps in sciences, maps that nowadays science still follows, of course under the auspice of contemporary data.

Around the 1st century BC, the muscular power of man and animals for the rotation of the millstones was replaced by the energy of water and the first watermills were constructed at that time. This innovation allowed the grinding of greater quantities of wheat seeds, so as to cover the needs of the developing urban centers. Strabo (from $64 \mathrm{BC}$ to $19 \mathrm{AD}$ ) was the first writer who mentioned the mills with water as motive power, and he called them "ydraletas." He supported that the older watermill belonged to the King Mithridates of Pontus (132-63 BC). According to Vallianos [76], the mathematician, physicist and engineer Heron of Alexandria (1st cent BC), Director of the Alexandrian Library, was the inventor of the watermill, although there are not any ancient references to confirm this suggestion.

\section{Water and Health}

Humans have spent most of their lives hunting and gathering food and people were constantly on the move. It has been postulated that the waterborne health risks of hunter-gatherers were small. As a result, people were occasionally troubled by pathogens transmitted by contaminated water. Later, sedentary agricultural life made it possible to construct villages, cities and eventually states, all of which were highly dependent on water. This created a brand-new relation between humans and water. Pathogens transmitted by contaminated water became a very serious health risk for the sedentary agriculturists. In this world, guaranteeing pure water for people became a prerequisite for successful urbanization and state formation.

People who lived in the Mediterranean basin during antiquity suffered from several water-related diseases. Malaria was among the serious health problems of that period, as documented by Greek and Roman medical authors. Another disease was schistosomiasis (bilharzia) which was also a scourge for Egypt and lasted more than a millennium. It is believed that the irrigation and flooding events of the Nile were responsible for the spreading of the disease. Paleopathological findings suggest that schistosomiasis in human remains from ancient Egypt [77].

Ancient Greek philosophers and doctors (e.g., Plato, Hippocrates, Herodotus and their students) have highlighted the importance of hot and cold for human health. For example, Plato in Politeia recommend the patients to have hot bath as a mean to cure their diseases. Furthermore, Aristotle highlights the value of bathing against fever and nasal hemorrhage [78]. Among the firsts who made observations on bathing therapy was Herodotus and his work is still acceptable by scientific community. Furthermore, Hippocrates highlighted the positive effect of bathing on resistance to disease. He also understood the negative effect on health of the extreme conditions such as the cold or hot water. Hippocrates also knew the importance of clean and boiled water for wound healing and recognized the therapeutic value of marine baths [79-81]. In Aphorisms, Hippocrates stated that "Life is short, and art is long, opportunity is fleeting, experience is perilous, and judgement is difficult" [82].

A famous medical school was established in Great Alexandria in ca. the third century BC, in which medical research became world renowned [83]. Although it was mainly Greek, following the teachings of Hippocrates, it was influenced by the medical practices in ancient Egypt. Among the most eminent investigators of this school were the Aristotelian physicians Herophilus (335-280 BC) and Erasistratus. That School was considered as the most important medicine center in the ancient world and lasted for about four centuries. Then, Greek physicians (e.g., Asclepiades and Galen) moved from Alexandria to Rome and transferred the knowledge there [83]. Greeks imported Egyptian substances into their 
pharmacopoeia, and the influence became more pronounced after the establishment of a school of Greek medicine in Alexandria [84].

In addition to the medical school, the ancient Library of Alexandria was considered the zenith of learning for over six centuries. To this day, it symbolizes the noblest aspirations of the human mind, global ecumenism, and the greatest achievements of the intellect [83]. The library completely disappeared over sixteen hundred years ago, but it continues to inspire scientists and scholars everywhere (Figure 16).

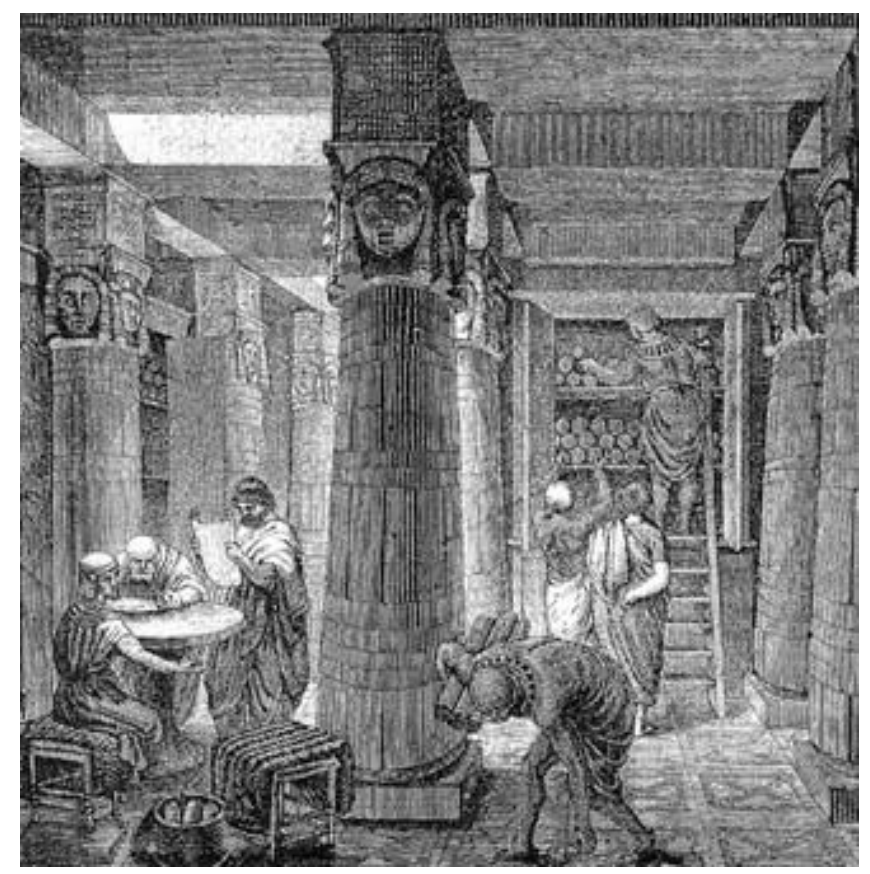

Figure 16. The Library of Alexandria based on some archaeological evidence [81].

\section{Discussion}

Ancient Greece goes back to Mycenaean culture of the second half of the second millennium BC. However, Egyptian civilization is much earlier than that: in the mid-second millennium BC, it was at its height (the "New Kingdom"), but its origins go right to the third millennium BC, or even earlier. From the early Minoan Era, the seafaring Greeks were frequent visitors to Egypt. Some of the visits were for trade (there was a Greek trading-base at Naucratis in Egypt from about this time), some of them were about military services, and some of them were probably just sightseeing.

Additionally, both civilizations were developed in parallel since the early Bronze Age (ca. 3200 BC). The Minoan period is characterized by developing extensive trade between Crete and eastern Mediterranean settlements. Through their traders and artists, the Minoans' cultural influence reached beyond Crete to the Old Kingdom of Egypt, the Levantine coast and Anatolia. Some of the best Minoan art is preserved in the city of Akrotiri on the island of Santorini (Thera), which was destroyed by the Thera eruption. Evans (1921-1935) and later archaeologists used relative chronology, based on pottery styles and imported Egyptian artifacts (which can be correlated with the Egyptian chronology), in developing Evans' chronological system, which divides the Minoan period into three major eras: early (EM), middle (MM) and late (LM).

Connections between Egypt and Crete are prominent; Minoan ceramics are found in Egyptian cities, and the Minoans imported items (particularly papyrus) and architectural and artistic ideas from Egypt [85]. Finally, Hood [86] reported that date palm trees and cats (for hunting) were imported by Minoans from Egypt. Besides raw materials, imported from the nearest known mines, which appear as far as Spain, Britain, central Europe and Iran, the Minoans also adopted from the surrounding cultures 
artistic ideas and techniques as evident in Egypt's influence on the Minoan wall frescoes. In addition, several precious metals used in the manufacturing of Cretan jewelry come from Egypt. Connections of Minoans with Egyptians and other Easter Mediterranean cultures is also justified by imported hippopotamus ivory, carnelian, amethysts, silver and probably gold [87]. She is also reported that silver was imported to Crete since pre-Dynastic Egypt. Rich tombs of an elite aristocracy are spreading (e.g., Archanes, Malia and Mochlos) and are indications of contacts with the eastern Mediterranean and of course Egyptians.

By the fifth-fourth century BC, Greek intellectuals had recognized the value and the great influence of Egyptian culture in ancient Greece. A typical example was the historian Herodotus who argued the Greek religion had its roots in Egypt.

The Nile river influenced greatly the Egyptian civilization which was established, grew and flourished mostly around the riverbanks. The main reason for that was the annual flooding of the river that provided water agricultural activities and supported urbanization and other non-agricultural activities. By contrast, the Ancient Greeks preferentially established in dry areas to protect their cities from catastrophic phenomena, which led to the fact that major Greek cities suffered from water scarcity phenomena due to low water availability. This was the case both on the continental and the insular country, since the Bronze Age [88]. Moreover, settlements on the top of hills or on rocky areas were common in ancient Greece to protect population and lands with high fertility [89].

Both ancient Egyptians and Greeks were well aware of the importance of sustainable use of water resources. The Egyptians, it is argued, had understood the natural water cycle of the Nile [90], a fact that enabled them to grow in harmony with the environment. The ancient Greeks also recognized the need for proper water management, which is depicted in their constructions and architecture. Together with the Egyptians, the Greeks recognized the importance and benefits of the mental well-being of their people, which is why they worked systematically to provide housing units that provided harmony and tranquility.

The Classical Era of ancient Greece (between 480 and until 323 BC) began with the victory of Greeks over the Persians. It is the period in which the Greeks pioneered art, science and philosophy. Well-known are the achievements of Athens and Sparta, cities that dominated the Hellenic world. The city of Athens first introduced to the world the direct Democracy. Well-known is also the influence of the thinkers of the Classical Greek era (e.g., Socrates, Plato, Hippocrates and Aristotle) in the last two thousand years; Hippocrates is considered as the Father of modern medicine, whereas his "Hippocratic oath" is still in use.

The peak of the Ancient Egyptian Empire was during the New Kingdom period (ca. 1550-1069 BC). Throughout the period from the end of the eleventh century BC until the fourth century BC, different foreign powers and native dynasties competed for control over the areas that the Ancient Egyptian Empire had controlled, displacing each other in turn and dividing the Nile Valley. Twice during the 6th and 4th centuries BC, the Achaemenid Persian Empire conquered Egypt before being displaced finally by the Greek led by Alexander the Great in 332 BC.

During the Hellenistic times, a type of "School of Mechanics" was founded in Alexandria. Greeks and Egyptians coexisted harmoniously in that School. The most prominent representatives of this group of mechanics were Archimedes from Syracuse (287-212 BC), Ctesibius (285-222 BC), Philon from Byzantium (260-180 BC), Biton Takticus (150-80 BC), Heron from Alexandria (ca. 10-70 AD), Athenaeus Mechanicus (50-50 BC) and Pappus of Alexandria (ca. 290-350 AD). Some of their innovations are mentioned by ancient writers but in the meantime are referred to in Egyptian papyruses, as well [75].

According to Greek religion, trees and gardens were considered places where the divine often visited. That is why most Greek houses in Athens had courtyards and gardens. Especially those who were rich could enjoyed extensive and rich gardens or places for recreation. There were also houses on the slopes of the outskirts of Athens which had terraces and gardens. The use of gardens, as well as fountains, in homes in Athens helped ensure the harmonious life of the inhabitants. 
In conclusion, Greeks and Egyptians coexisted since the early Bronze Age. Not only that but they also established a harmonious collaboration especially after Alexandria was founded by the Alexander the Great. Close inspection of the bibliography reveals that numerous hydraulic inventions and discoveries occurred at that time, as identified in the History of Hydraulics [91]. Characteristic examples are: the water wheel (ca. 3rd century BC), the water mill (ca. $250 \mathrm{BC}$ ), the air and water pumps (ca. 2nd century BC), the Archimedes' screw (ca. 3rd century BC), the alarm clock (ca. 3rd century $\mathrm{BC}$ ), and the first recorded steam engine (known as aeolipile) almost two millennia before the industrial revolution [28].

Review results herein showed that dams and canals were constructed in ancient Egypt to control Nile river flooding and develop irrigation systems since ca. 6000 BC. In the 2nd millennium BC, Minoans regulated the flow of the streams by using a system of two dams in order to prevent soil erosion of the arable lands and to irrigate agricultural fields. Results showed also that ancient Egyptians invented many devices for lifting water for plant irrigation such as the shadouf, sakia and tympanum which some of them are already in use in Mesopotamia for irrigating small plots. Ancient Greece also adopted and improved these devices. Results confirmed that recorded evidences of water management for irrigation were proofed for both ancient civilizations. For water level monitoring of the Nile river, ancient Egyptians established many indicators for recording water level every year which, they are too close to what is in use recently. Table 2 concluded the major technical differences and similarities between Egyptian and Greek Hydro technologies.

Table 2. The major technical differences and similarities between Egyptian and Greek hydro technologies.

\begin{tabular}{|c|c|c|}
\hline Comparison Items & Egyptian Civilization & Greece Civilization \\
\hline \multicolumn{3}{|c|}{ Differences } \\
\hline Location & South Mediterranean Sea & North Mediterranean Sea \\
\hline The peak of the ancient empire & Began with the New Kingdom period & $\begin{array}{l}\text { Began with the victory of Greeks over } \\
\text { the Persians }\end{array}$ \\
\hline Agriculture & $\begin{array}{l}\text { Farm a large-scale land and developed } \\
\text { innovation like ox-drawn plow }\end{array}$ & $\begin{array}{l}\text { Farmed small-scale lands and adopted } \\
\text { agriculture activities late }\end{array}$ \\
\hline Water lifting devices for irrigation & $\begin{array}{l}\text { Very early invented shadouf and } \\
\text { paddle-driven water-lifting wheels }\end{array}$ & $\begin{array}{l}\text { Later invented the Archimedes screw } \\
\text { and Ktesibius pump }\end{array}$ \\
\hline \multicolumn{3}{|c|}{ Similarities } \\
\hline $\begin{array}{l}\text { Water harvesting by using cisterns } \\
\text { and aqueducts }\end{array}$ & Adopted very early & Adopted very early \\
\hline $\begin{array}{l}\text { Quality and security of the water } \\
\text { supply systems }\end{array}$ & Significantly considered & Significantly considered \\
\hline Water management & Similar of recent principles & Similar to recent principles \\
\hline Simplicity of water technologies & Simple and easy to use & Not requiring complex controls \\
\hline $\begin{array}{l}\text { Sustainability of water } \\
\text { technologies }\end{array}$ & Used up to the current time & Sustainable even for coming times \\
\hline
\end{tabular}

\section{Epilogue: Lessons Learned}

The pioneering technological achievements by the two civilizations had no example in prior human history. The similarities among the two civilizations, especially in the hydro-technologies development, are strongly refereed by the significant contact with each other. It should be noticed that the basic technologies developed by both civilizations are in principle identical. Moreover, the major difference is the scale used. 
Besides sustainability, aspects of the hydro-technology structures were discussed in this review, and there are many lessons which could be learned for modern water supply and management engineering, such as the following.

(a) The importance of sanitation, water supply and drainage and sewerage systems for human survival and well-being was significantly understood by Egyptian and Greek civilizations to achieve water resource sustainability.

(b) Water technologies in both civilizations were featured by their simplicity, not requiring complex controls, and being easy to use. This makes these technologies more sustainable. These systems exhibited massive achievements in engineering due to their wonderful design and operation schemes.

(c) Both civilizations adopted cisterns for water harvesting as one of the small-scale systems. Aqueducts were used as one of large-scale water supply projects for large water flows like many ancient civilizations after that.

(d) Many of the water systems established by ancient Egyptians and Greeks should be considered as potential models for sustainable water technologies for the current and the coming times not only as historical items.

(e) In both civilizations, water quality and security of the water supply systems were considered significantly by ancient people. Water security included adequate water supply and safety.

(f) Intensification of unresolved problems led societies to revisit the past and reinvestigate successful past achievements, especially those related to water technologies. Those who attempted this retrospect, based on archaeological, historical and technical evidence, were impressed by the similarity of principles with present ones and the high level of water engineering and management practices in ancient civilizations, e.g., Egyptians and Greeks [6,16,92].

(g) To sum up, due to the shortage in the water demand worldwide and particularly in regions of the developing world, there is a great need for water supply and sanitation facilities with sustainable and cost-effective systems [17]. Adopting ancient water supply management systems such as the storage of rainfall runoff facilities may be introduced as an effective solution for water scarcity.

(h) Finally, it is well known that the young have a greater risk attitude than older people and thus the early civilizations (e.g., Egyptians and Greeks) were more genuine, spontaneous and instinctive, as well as having greater risk attitudes that led them towards the construction of wonderful and fantastic hydraulic works, and a better understanding of the human needs and wishes [92]. In the perspective of water and wastewater technologies, this is particularly true because water is the beginning of life, as stated by Aristotle (384-322 BC; Metaphysics, $983 \mathrm{~b}$ ). Thus, we have to recover the ability to 'think young' - to 'think sustainable' [93].

Author Contributions: Conceptualization, A.N.A.; writing-original draft preparation, A.T.A., F.E.G. and A.N.A.; writing-review and editing, A.T.A., F.E.G., V.A.T. and A.N.A.; supervision, A.N.A. All authors have read and agreed to the published version of the manuscript.

Funding: This research received no external funding.

Conflicts of Interest: The authors declare no conflict of interest.

\section{References}

1. Broad, W.J. History of Minoan Crete. Ancient Greece. Available online: https://ancient-greece.org/history/ minoan.html (accessed on 30 September 2020).

2. Bealby, M.A. Aegean-Egyptian Relations c 1900-1400 BC. Ph.D. Thesis, University of Birmingham, Birmingham, UK, 2014.

3. Dalachanis, A. The Greek Exodus from Egypt: Diaspora Politics and Emigration 1937-1962; Berghann: London, UK, 2017; ISBN 978-1-78533-447-4. 
4. Villing, A. Naukratis: A City and Trading Port in Egypt; Trustees of the British Museum: London, UK, 2019; Available online: https://research.britishmuseum.org/research/online_research_catalogues/ng/naukratis_ greeks_in_egypt/introduction/naukratis_a_city_and_port.aspx (accessed on 30 September 2020).

5. Garnett, R. Did the Greeks Borrow Egyptian Gods? The Straight Dope. 2004. Available online: https://www.straightdope.com/columns/read/2146/did-the-greeks-borrow-egyptian-gods/ (accessed on 30 September 2020).

6. Angelakis, A.N.; Koutsoyiannis, D.; Tchobanoglous, G. Urban wastewater and stormwater technologies in ancient Greece. Water Res. 2005, 39, 210-220. [PubMed]

7. Pollard, J.; Reid, H. The Rise and Fall of Alexandria: Birthplace of the Modern World; Penguin Books: London, UK, 2007; p. 329.

8. De Feo, G.; Angelakis, A.N.; Antoniou, G.P.; El-Gohary, F.; Haut, B.; Passchier, C.W.; Zheng, X.Y. Historical and technical notes on aqueducts from prehistoric to medieval times. Water 2013, 5, 1996-2025.

9. History-Ancient Period. Available online: http://web.cocc.edu/cagatucci/classes/hum213/Maps/ Maps2HistoryAncient.htm (accessed on 30 October 2020).

10. Zaki, A.; Swelam, A. First Report Climatology of Nile Delta, Egypt; ICARDA: Beirut, Lebanon, 2017.

11. The Weather Channel, (TWC). 2020. Available online: https://weather.com/news/news/2018-03-19-ancientegyptians-prepped-for-climate-change (accessed on 30 April 2020).

12. Manning, J.G.; Ludlow, F.; Stine, A.R.; Boos, W.R.; Sigl, M.; Marlon, J.R. Volcanic suppression of Nile summer flooding triggers revolt and constrains interstate conflict in ancient Egypt. Nat. Commun. 2017, 8. [CrossRef]

13. Markonis, Y.; Batelis, S.C.; Dimakos, Y.; Moschou, E.; Koutsoyiannis, D. Temporal and spatial variability of rainfall over Greece. Theor. Appl. Climatol. 2016. [CrossRef]

14. Angelakis, A.N.; Voudouris, K.; Mariolakos, I. Groundwater utilization through the centuries with emphasis on Hellenic civilizations. Hydrogeol. J. 2016, 24, 1311-1324. [CrossRef]

15. Krasilnikoff, J.; Angelakis, A.N. Water management and its judicial contexts in ancient Greece: A review from the earliest times to the Roman period. Water Policy 2019. [CrossRef]

16. Koutsoyiannis, D.; Zarkadoulas, N.; Angelakis, A.N.; Tchobanoglous, G. Urban water management in ancient Greece: Legacies and lessons. ASCE J. Water Resour. Plan. Manag. 2008, 134, 45-54.

17. Khan, S.; Dialynas, E.G.; Kasaraneni, V.K.; Angelakis, A.N. Similarities of Minoan and Indus Valley Hydro-technologies. Sustainability 2020, 12, 4897. [CrossRef]

18. Kalavrouziotis, I.K.; Angelakis, A.N. (Eds.) Prolegomena. In Proceedings of the IWA Regional Symposium on Water, Wastewater and Environment: Traditions and Culture, (E-Proceedings), Hellenic Open University, Patras, Greece, 22-24 March 2014.

19. Butzer, K.W. Early Hydraulic Civilization in Egypt; Oriental Institute: Chicago, IL, USA, 1976.

20. Yannopoulos, S.I.; Lyberatos, G.; Theodossiou, N.; Li, W.; Valipour, M.; Tamburrino, A.; Angelakis, A.N. Evolution of Water Lifting Devices (Pumps) over the Centuries Worldwide. Water 2015, 7, 5031-5060. [CrossRef]

21. Haldane, J.; Henderson, Y. The Rate of Work done with an Egyptian Shadouf. Nature 1926, 118, 308-309.

22. Lazos, C.D. Hydraulic Equipment and Mechanism; Aeolus: Athens, Greece, 1999. (In Greek)

23. Wikander, O. Sources of energy and exploitation of power. In the Oxford Handbook of Engineering and Technology in the Classical World; Oleson, J.P., Ed.; Oxford University Press: Oxford, UK, 2008; Chapter 6; ISBN 978-0-19-518731-1. Available online: https://www.oxfordhandbooks.com/view/10.1093/oxfordhb/ 9780199734856.001.0001/oxfordhb-9780199734856 (accessed on 30 September 2020).

24. Oleson, J.P. Greek and Roman Mechanical Water-Lifting Devices: The History of a Technology; University of Toronto Press: Toronto, ON, Canada, 1984; ISBN 90-277-1693-5.

25. De Miranda, A. Aesthetic Tradition and Ancient Technology: A case study of the Waterwheel. Design and Nature II; WIT Press: Southampton, UK, 2004; ISBN 1-85312-721-3.

26. Vullo, V. Gears: A Concise History; Springer Series in Solid Structure Mechanics; Springer Nature Switzerland: Cham, Switzerland, 2020; Volume 3.

27. De Miranda, A. Water Architecture in the Lands of Syria: The Water-Wheels; L'Erma di Bretschneider: Rome, Italty, 2007.

28. Tassios, T. A Potential Steam-Powered Force Pump in Hellenistic Times (ca 330-67 BC); International Water Association: London, UK, 2015; p. 4.

29. Hurst, K.S. Engineering Design Principles; John Wiley and Sons: New York, NY, USA, 1999; p. 172. 
30. Strouhal, E. Life in Ancient Egypt; Cambridge University Press: Cambridge, UK, 1992.

31. Mays, L.W. Survey of ancient water technologies in semi-arid and arid regions: Traditional knowledge for the future. Water Supply 2017, 17, 1278-1286. [CrossRef]

32. Garbrecht, G. The "Sadd el Kafara", the world's oldest dam. Special Session on History of Irrigation. In Proceedings of the 12th ICID Congress, Colorado State University, Fort Collins, CO, USA, 28 May-2 June 1984.

33. Bazza, M. Overview of The Hystory of Water Resources and Irrigation Management in The Near East Region. In Proceedings of the 1st IWA International Symposium on Water and Wastewater Technologies in Ancient Civilizations, Herklion, Greece, 28-30 October 2006.

34. Jansen, R.B. Dams from the Beginning; Springer: Berlin, Germany, 2010.

35. Fahlbusch, H. Early Dams; History Association: London, UK, 2010; Available online: https://www.history.org. uk/ (accessed on 30 September 2020).

36. Schnitter, N. A History of Dams; Balkema: Rotterdam, The Netherlands, 1994; p. 266.

37. Water History. Available online: www.waterhistory.org (accessed on 30 October 2020).

38. Angelakis, A.N. Hydro-technologies in Minoan Era. Water Sci. Technol. Water Supply 2017, 17, 1106-1120. [CrossRef]

39. HYDRIA Project. Water Management in Prehistoric Crete: The case of Choiromandres, Zakros. HYDRIA Project Collection, Storage and Distribution of Water in Antiquity Linking Ancient Wisdom to Modern Needs 2011. Available online: http://www.hydriaproject.net/en/greece-cretewater (accessed on 30 September 2020).

40. Krasilnikoff, J.A. Irrigation as innovation in ancient Greek agriculture. World Archaeol. 2010, 42, $108-121$.

41. Bowe, P. Civic and other public planting in ancient Greece. Stud. Hist. Gard. Des. Landsc. 2011, 31, $269-285$.

42. The Food and Agriculture Organization (FAO). Ancient Egyptian Agriculture. 2020. Available online: http://www.fao.org/country-showcase/item-detail/en/c/1287824/\#: \{\}:text=Egyptians\%20are\%20credited\% 20as\%20being, agriculture $\% 20$ on $\% 20$ a $\% 20$ large $\% 20$ scale.\&text=Their\%20farming $\% 20$ practices $\%$ 20allowed\%20them, such\%20as\%20flax\%20and\%20papyrus (accessed on 30 October 2020).

43. Argolikos Archival Library of History and Culture. Plow Naphplion, Greece. 2013. Available online: https://argolikivivliothiki.gr/2013/01/18/aletri/ (accessed on 18 October 2020). (In Greek).

44. Totsikas, A. Greek Folk Heritage: Tools and Constructions of the Material of Traditional Life; Armos Publications: Athens, Greece, 2008. (In Greek)

45. Isager, S.; Skydsgaard, J.E. Ancient Greek Agriculture: An Introduction; Routledge: Abingdon, UK, $1995 ;$ p. 41. ISBN 0-415-11671-6.

46. Lightfoot, D. Survey of Infiltration Karez in Northern Iraq: History and Current Status of Underground Aqueducts; Report IQ/2009/SC/RP/1; United Nations Educational, Scientific and Cultural Organization (UNESCO): Paris, France, 2009.

47. Salem, M.; Bakry, A. Ancient Qanat System in Qasr Allam (Bahariya Oasis). J. Sci. Res. Lit. 2019, 20, 341-363.

48. La Moreaux, P.E.; Tanner, J. Springs and Bottled Waters of the World; Springer: Berlin, Germany, 2001.

49. Earthmilk Ancient Energy (EAE). Precisely Cut Wells, Shafts, and Underground Channels Connecting the Pyramids to the Nile River. 2015. Available online: http://earthmilkancientenergy.com/ch4.htm (accessed on 30 September 2020).

50. Ahmed, A.T. Water Quality for Irrigation and Drinking Water Use of Aflaj in Oman. Water Sci. Technol. Water Supply 2015, 15, 421-428.

51. Stiros, S.C. Accurate measurements with primitive instruments: The "paradox" in the qanat design. J. Archaeol. Sci. 2006, 33, 1058-1064.

52. Wulff, H.E. The qanats of Iran. Sci. Am. 1968, 4, 94-105.

53. Wuttmann, M.; Gonon, T.; Thiers, C. The Qanats of 'Ayn Manawir (Egypt). In Proceedings of the First International Symposium on Qanat, Yazd, Iran, 8-11 May 2000; pp. 162-169.

54. Sun, Q.; Tao, W.; Kobori, I.; Liang, L. Case Study V: Karez in the Turpan region of China. In Seeing Traditional Technologies in a New Light Using Traditional Approaches for Water Management in Drylands; Bigas, H., Adeel, Z., Schuster, B., Eds.; United Nations Educational Scientific and Cultural Organization: Paris, France, 2009.

55. Voudouris, K.; Christodoulakos, Y.; Stiakakis, M.; Angelakis, A.N. Hydrogeological Characteristics of Hellenic Aqueducts-like Qanats. Water 2013, 5, 1326-1345. 
56. EPA. The History of Drinking Water Treatment. Environmental Protection Agency, Office of Water (4606), Fact Sheet EPA-816-F-00-006 United States. 2000. Available online: https:/www.lenntech.com/history-watertreatment.htm\#ixzz6ZVp9GmkW (accessed on 30 September 2020).

57. Jadhav, A.S. Review Article Advancement in Drinking Water Treatments from Ancient Times. Int. J. Sci. Environ. Technol. 2014, 3, 1415-1418.

58. Baker, M.N.; Taras, M.J. The Quest for Pure Water: The History of theTwentiethCentury; American Water Works Association (AWWA): Denver, CO, USA, 1981; Volumes 1 and 2.

59. Defner, M. Late Minoan Water Treatment Device. Archaeological Newspaperno 1921, 78. (In Greek) [CrossRef]

60. Spanakis, S. The Water Supply of Iraklion. Tech. Chamb. Greece Iraklio 1981, 828-1939. (In Greek). Available online: http://library.tee.gr/vufind/Record/10028966/Details (accessed on 30 September 2020).

61. Hatzidakis, J. Les Villas Minoennes de Tylissos; Version Francaise de Chapouthier el R.; Etudes Cretoises, J., III, Ed.; Librairie Orientaliste Paul Geuthner: Paris, France, 1934. (In French)

62. Angelakis, A.N.; Voudouris, K.S.; Tchobanoglous, G. Evolution of Water Supplies in the Hellenic World Focusing on the Water Treatment and Modern Parallels. Water Supply 2020. [CrossRef]

63. Dunn, J. The Cisterns of Alexandria. Tour Egypt. 2011. Available online: http://www.touregypt.net/ featurestories/alexandriacisterns.htm (accessed on 30 October 2020).

64. Driaux, D. Water supply of ancient Egyptian settlements: The role of the state. Overview of a relatively equitable scheme from the Old to New Kingdom (ca. 2543-1077 BC). Water Hist. 2016, 8, 43-58. [CrossRef]

65. El-Gohary, F.A. Evolution of sanitation and wastewater technologies in Egypt. In Evolution of Sanitation and Wastewater Technologies Through Centuries; Angelakis, A.N., Rose, J.B., Eds.; IWA Publishing: London, UK, 2014; Chapter 4; pp. 55-68.

66. Evans, S.A. The Palace of Minos at Knossos: A Comparative Account of the Successive Stages of the Early Cretan Civilization as Illustrated by the Discoveries; Macmillan and Co.: London, UK, 1935; Volume IV, (reprinted by Biblo and Tannen, New York, USA, 1964).

67. Angelakis, A.N.; Kavoulaki, E.; Dialynas, M.G. Sanitation and stormwater and wastewater technologies in minoan era. In Evolution of Sanitation and Wastewater Management through the Centuries; Angelakis, A., Rose, J., Eds.; IWA Publishing: London, UK, 2014; Chapter 1; pp. 1-24.

68. Angelakis, A.N. Evolution of Rainwater Harvesting and Use in Crete, Hellas through the Millennia. Water Sci. Techn. Water Supply 2016, 16, 1624-1638. [CrossRef]

69. Graham, J.W. The Palaces of Crete, Revised Ed; Princeton University Press: Princeton, NJ, USA, 1987.

70. Mosso, A. Escursioni nel Mediterraneo e gli scavi di Creta; Treves: Milano, Italy, 1907.

71. Gray, H.F. Sewerage in Ancient and Medieval Times. Sew. Work. J. 1940, 12, 939-946.

72. Boulud, S. Terra Santa: L'Eau et le Réseau Hydraulique Antique, Centre d'Études Alexandrines; CEAlex: Alexandria, Egypt, 2011.

73. Hairy, I. (Ed.) L'Eau Alexandrine: Des Hyponomes Aux Citernes. In Du Nil à Alexandrie:Histoire d'eaux; Harpocrates Publishing: Alexandria, Egypt, 2011; pp. 212-239.

74. Yannopoulos, S.; Antoniou, G.; Kaiafa-Saropoulou, M.; Angelakis, A.N. Historical Development of Rainwater Harvesting and Use in Hellas: A Preliminary Review. Water Sci. Technol. Water Supply 2017, 17, 1022-1034.

75. Tsekos, C.A. The Search of Water Resources Via Time in Greece. B.S. Thesis, Department of Natural and Natural Resources Management, University of Ioannina, Ioannina, Greece, 2003.

76. Vallianos, P.W. The Attitude of the three Hierarchs towards knowledge and learning. Greek Orthodox. Theol. Rev. 1997, 24, 1.

77. Vuorinen, H.S.; Juuti, P.S.; Katko, T.S. History of water and health from ancient civilizations to modern times. Water Sci. Technol. Water Supply 2007, 7, 49-57.

78. Tsitsis, N.; Polkas, G.; Daoutis, A.; Prokopiou, E.; Kourkouta, L. Hydrotherapy in Ancient Greece. Balk. Mil. Med. Rev. 2013, 16, 462-466.

79. Mooventhan, A.; Nivethitha, L. Scientific Evidence-Based Effects of Hydrotherapy on Various Systems of the Body. N. Am. J. Med. Sci. 2014, 6, 199-209. [PubMed]

80. Sazakli, E.; Sazaklie, E.; Leotsinidis, M.; Varnavas, S.P. Hydrotherapy: An ancient Art, legacy of Hippocrates, the father of medicine. In Proceedings of the 4th IWA International Civilizations, Coimbra, Portugal, 17-19 September 2016. 
81. Fourla, D.-M. Statement by Deputy Foreign Minister Yiannis Amanatidis for the Ancient Ancestry of the Asclepieion Network with the Assistance of the General Secretariat for Greeks Abroad. 2018. Available online: http://www.readfree.gr/node/11142 (accessed on 11 October 2018).

82. Galanaki, M.E. Water Borne Diseases and Hippocrates: The Treatise on airs, waters, and places. In Evolution of Sanitation and Wastewater Management through the Centuries; Angelakis, A.N., Rose, J.B., Eds.; IWA Publishing: London, UK, 2014; Chapter 21; pp. 419-428.

83. Serageldin, I. Ancient Alexandria and the dawn of medical science. Glob. Cardiol. Sci. Pract. 2013, 2013, 395-404. [PubMed]

84. Von Staden, H. Herophilus: The Art of Medicine in Early Alexandria; Cambridge University Press: Cambridge, UK, 1989; pp. 1-26.

85. Bengtson, H. Griechische Geschichte. Von den Anfüngen bis in Die Römische Kaiserzeit, 9th ed.; C.H. Beck: München, Germany, 2002; ISBN 340602503X. (In German)

86. Hood, S. The Minoans; the Story of Bronze Age Crete; Praeger: New York, NY, USA, 1971.

87. Hickman, J. Gold Before the Palaces: Crafting Jewelry and Social Identity in Minoan Crete. Ph.D. Thesis, University of Pennsylvania, Philadelphia, PA, USA, 2008.

88. Zarkadoulas, N.; Koutsoyiannis, D.; Mamassis, N.; Papalexiou, S.M. Climate, Water and Health in Ancient Greece. In Proceedings of the European Geosciences Union General Assembly 2008, Geophysical Research Abstracts, Vienna, Austria, 13-18 April 2008; Volume 10.

89. Antoniou, G.; Lyberatos, G.; Kanetaki, E.I.; Kaiafa, A.; Voudouris, K.; Angelakis, A.N. History of urban wastewater sanitation technologies in Hellas. In Evolution of Sanitation and Wastewater Management through the Centuries; Angelakis, A., Rose, J., Eds.; IWA Publishing: London, UK, 2014; Chapter 6; pp. 101-148.

90. Nriagu, J. Environmental pollution and human health in ancient times. Encycl. Environ. Health 2011, 489-506. [CrossRef]

91. Rouse, H.; Ince, S. History of Hydraulics; The University of Iowa, Institute of Hydraulic Research: Iowa, IA, USA, 1957.

92. Mays, L.W. (Ed.) Ancient Water Technologies; Springer: Dordrecht, The Netherlands, 2010.

93. Angelakis, A.N.; Mays, L.W.; De Feo, G.; Salgot, M.; Laureano, P.; Drusiani, R. Topics and challenges on water history. In Global Trends and Challenges in Water Science, Research and Management: A Compendium of Hot Topics and Features from IWA Specialist Groups, 2nd ed.; Li, H., Ed.; IWA: London, UK, 2016; pp. 128-132.

Publisher's Note: MDPI stays neutral with regard to jurisdictional claims in published maps and institutional affiliations.

(C) 2020 by the authors. Licensee MDPI, Basel, Switzerland. This article is an open access article distributed under the terms and conditions of the Creative Commons Attribution (CC BY) license (http://creativecommons.org/licenses/by/4.0/). 